\title{
PAID FAMILY LEAVE, FATHERS' LEAVE-TAKING, AND LEAVE-SHARING IN DUAL-EARNER HOUSEHOLDS
}

\author{
Ann Bartel \\ Maya Rossin-Slater \\ Christopher Ruhm \\ Jenna Stearns \\ Jane Waldfogel \\ Working Paper 21747 \\ http://www.nber.org/papers/w21747
}

\author{
NATIONAL BUREAU OF ECONOMIC RESEARCH \\ 1050 Massachusetts Avenue \\ Cambridge, MA 02138 \\ November 2015
}

We thank Kelly Bedard, Shelly Lundberg, Jonathan Simonetta, Dick Startz, and seminar participants at UC Santa Barbara and the APPAM conference for helpful comments. We gratefully acknowledge funding from the Department of Labor Contract No. DOL-OPS-14-C-0003. Jane Waldfogel also acknowledges support from NICHD to the Columbia Population Research Center. All errors are our own. The views expressed herein are those of the authors and do not necessarily reflect the views of the National Bureau of Economic Research.

NBER working papers are circulated for discussion and comment purposes. They have not been peerreviewed or been subject to the review by the NBER Board of Directors that accompanies official NBER publications.

(C) 2015 by Ann Bartel, Maya Rossin-Slater, Christopher Ruhm, Jenna Stearns, and Jane Waldfogel. All rights reserved. Short sections of text, not to exceed two paragraphs, may be quoted without explicit permission provided that full credit, including $(\subset$ notice, is given to the source. 
Paid Family Leave, Fathers' Leave-Taking, and Leave-Sharing in Dual-Earner Households Ann Bartel, Maya Rossin-Slater, Christopher Ruhm, Jenna Stearns, and Jane Waldfogel NBER Working Paper No. 21747

November 2015

JEL No. J08,J13,J18,J2

\begin{abstract}
$\underline{\text { ABSTRACT }}$
This paper provides quasi-experimental evidence on the impact of paid leave legislation on fathers' leave-taking, as well as on the division of leave between mothers and fathers in dual-earner households. Using difference-in-difference and difference-in-difference-in-difference designs, we study California's Paid Family Leave (CA-PFL) program, which is the first source of government-provided paid parental leave available to fathers in the United States. Our results show that fathers in California are 0.9 percentage points - or 46 percent relative to the pre-treatment mean - more likely to take leave in the first year of their children's lives when CA-PFL is available. We also examine how parents allocate leave in households where both parents work. We find that CA-PFL increases father-only leave-taking (i.e., father on leave while mother is at work) by 50 percent and joint leave-taking (i.e., both parents on leave at the same time) by 28 percent. These effects are much larger for fathers of sons than for fathers of daughters, and almost entirely driven by fathers of first-born children and fathers in occupations with a high share of female workers.
\end{abstract}

Ann Bartel

Graduate School of Business

Columbia University

3022 Broadway, 623 Uris Hall

New York, NY 10027

and NBER

apb2@columbia.edu

Maya Rossin-Slater

Department of Economics

2127 North Hall

University of California

Santa Barbara, CA 93106-9210

maya.rossin-slater@ucsb.edu

Christopher Ruhm

Frank Batten School of

Leadership and Public Policy

University of Virginia

235 McCormick Rd.

P.O. Box 400893

Charlottesville, VA 22904-4893

and NBER

ruhm@virginia.edu
Jenna Stearns

2127 North Hall

University of California

Santa Barbara 93106

stearns@umail.ucsb.edu

Jane Waldfogel

Columbia University

School of Social Work

1255 Amsterdam Avenue

New York, NY 10027

jw205@columbia.edu 


\section{Introduction}

Paid family leave (PFL) policies provide workers with paid time off from work to care for their newborn or newly-adopted children, as well as other sick or elderly family members. PFL policies may be especially important for new parents, who often struggle with balancing the competing needs of work and family responsibilities. PFL allows them to stay home to care for and bond with their newborn children, and then return to work with minimal career interruptions. Although historically these policies only applied to women, some modern PFL programsincluding the three existing state-level programs in the United States in California, New Jersey, and Rhode Island-are gender-neutral and cover both male and female workers. Yet while an extensive literature has studied the implications of policies promoting work-family balance for women, much less attention has been devoted to the corresponding effects of these policies on men, or on joint leave-taking decisions within families where both parents work. ${ }^{1}$ This lack of understanding about the effects of such policies for fathers is particularly salient in view of recent evidence that fathers now report equal or greater levels of work-family conflict as do mothers (Auman et al., 2011; Rehel and Baxter, 2015).

This paper begins to fill this gap by analyzing how American fathers respond to the introduction of the country's first-in-the-nation large-scale PFL policy in California. We also break new ground by studying how fathers and mothers in dual-earner households share leavetaking responsibilities.

While advocates frequently credit work-family programs such as PFL with promoting gender equality and supporting women in their careers, increased leave-taking by fathers may have benefits that extend beyond any gains to women in the workplace. To the extent that gendered patterns of childcare provision develop early on, even relatively small changes in initial paternity leave decisions may have important long-run implications. Supporting this idea, several studies suggest that the amount of time fathers spend in childcare is correlated with the generosity of paternity leave policies (Fuwa and Cohen, 2007; Boll et al., 2014) and that fathers who take more leave around the time of birth may be more involved in childcare not only during the

\footnotetext{
${ }^{1}$ Studies on the effects of work-family policies on women's labor market outcomes are abundant. See, for example, work on maternity leave (Waldfogel, 1999; Rossin-Slater, Ruhm, and Waldfogel, 2013; Baum and Ruhm, 2015) and childcare (Waldfogel, 2002; Lefebvre and Merrigan, 2008; Baker, Gruber, and Milligan, 2008; Havnes and Mogstad, 2011; Fitzpatrick, 2012).
} 
period of leave, but throughout the child's life (Haas, 1990; Nepomnyaschy and Waldfogel, 2007; Tanaka and Waldfogel, 2007; Haas and Hwang, 2008). While these correlations may not be surprising given positive selection into leave-taking, recent evidence from Quebec suggests there may be a causal effect of exposure to parental leave policies on long-term paternal involvement as well (Patnaik, 2015). There could also be other benefits related to the health and well-being of family members and longer-term effects on gender norms and role-models (Ray, Gornick, and Schmitt, 2008).

The extent to which such benefits may materialize crucially depends on a first-order question of whether fathers take up leave when PFL is offered. This question remains largely unanswered, especially in the U.S. context. While evidence suggests that women increase their leave-taking in response to PFL availability (Rossin-Slater, Ruhm, and Waldfogel, 2013; Baum and Ruhm, 2015), men may be less receptive to taking time off work either because they view it as too costly or because of stigma associated with gender stereotypes and norms about childcare. Additionally, while most employers still do not offer paid parental leave, more cover paid maternity leave than paternity leave (Klerman, Daley, and Pozniak, 2012). To the extent that it is harder for them to take time off in the absence of a government-provided PFL policy, new fathers might be more responsive to widespread access to paid leave. Finally, the benefits of paternity leave may depend on whether fathers stay home with their child alone, or whether they take leave alongside mothers. We know even less about the related question of how the availability of paid leave influences the joint leave-taking behavior of fathers and mothers in households where both parents work. This paper provides some of the first quasi-experimental evidence on these questions.

Our analysis exploits the introduction of California's first-in-the-nation paid family leave (CA-PFL) program in July 2004. CA-PFL offers six weeks of paid leave to new parents, with a 55 percent wage replacement rate up to a ceiling (a maximum benefit of $\$ 1,104$ per week in 2015) and with almost universal eligibility among private sector workers. ${ }^{2}$ We use data from the 2000 Census and the 2000-2013 waves of the American Community Survey (ACS) together with

\footnotetext{
${ }^{2}$ To be eligible for the program, individuals are required to have worked at least 300 hours during a "base period" five to seventeen months before the birth. The program is tightly integrated with California's temporary disability insurance system, which provides several weeks of paid leave to mothers (but not fathers) around the period of delivery. The paid leaves are not directly job-protected but job-protection is available if the job absence simultaneously qualifies under the Family and Medical Leave Act. Additional information on the California program is available at http://www.edd.ca.gov/disability/FAQ_PFL_Benefits.htm.
} 
difference-in-difference (DD) and difference-in-difference-in-difference (DDD) methods to identify the causal effects of CA-PFL on paternal leave-taking. Our preferred DDD specification compares employed fathers of infants in California to employed fathers of children aged one to three, relative to corresponding fathers of the same age children in other states, before and after the introduction of California's PFL program. We perform an analogous analysis of mothers to enable comparisons of effects across parental gender. Further, we explore within-household leave-taking behavior in households where both parents work by studying "father only" (i.e., father is on leave while mother is at work), "mother only" (i.e., mother is on leave while father is at work), "both parent" (i.e., both the father and mother are on leave at the same time), and "either parent" (i.e., either the mother or the father is on leave) leave-taking outcomes.

In our preferred specification, CA-PFL is estimated to raise the share of fathers of infants who are on leave by about 0.9 percentage points. Relative to the pre-PFL mean leave-taking rate among California fathers of infants of 2 percent, this represents a substantial 46 percent increase. Among households with two married and employed parents, we see that about half of this increase is driven by fathers who take leave at the same time as their children's mothers and the other half by fathers who take leave on their own while their children's mothers are at work.

We also document significant heterogeneity in paternal leave-taking. First, the overall effect of CA-PFL on fathers' leave-taking is about twice as large for fathers of sons than for fathers of daughters. In contrast, the effect on mothers' leave-taking is larger for mothers of daughters than mothers of sons. Second, we show that the effects on leave-taking are driven entirely by fathers of first-born children (i.e., those with no other siblings in the household). There are no such differences for mothers. Third, fathers and mothers in occupations with a high share of female workers experience greater increases in leave-taking than their counterparts in occupations with a lower share of female employees. While there are a number of explanations for this type of treatment effect heterogeneity, one possibility is that individuals in occupations with more women experience less stigma associated with taking leave.

Our findings are robust across a variety of alternative DD and DDD specifications, and to the inclusion of numerous individual-level and state-year controls. We demonstrate that there are no statistically significant pre-trends in leave-taking behavior in the years before CA-PFL and obtain similar findings when collapsing the data to the state-year level and using synthetic control methods with a variety of control groups. This consistency of estimates increases our 
confidence that we are accurately measuring causal effects of CA-PFL, although we do note several limitations of the data in subsequent sections.

\section{Background}

Currently, all industrialized countries other than the United States have some kind of national paid parental leave policy (Earle, Mokomane, and Heymann, 2011). The most generous policies are found in Europe, where the length of paid leave varies from 3.5 to 38 months with 70 to 100 percent of wages replaced, and two-thirds of developed countries provide some (albeit generally more limited) rights for fathers to take leave (Ruhm, 2011). However, the take-up rate of parental leave by fathers is generally substantially lower than by mothers. In recent years, policy makers have made a concerted effort to encourage fathers to take more time off. Studies show that several countries including Sweden (Duvander and Johansson, 2012; Ekberg et al., 2013), Norway (Dahl et al., 2014), and parts of Canada (Patnaik, 2015) have substantially increased rates of fathers' leave-taking by incorporating dedicated paternity leave into their general parental leave policy (sometimes referred to as "daddy quotas" or "daddy months"). There is some evidence that these reforms also increase the amount of childcare provided by fathers, both in the child's first year of life and 18-30 months later (Schober, 2014).

However, most existing research on PFL policies is exclusively focused on mothers. Studies from Canada and Europe find very high leave take-up rates among mothers (Rønsen and Sundström, 2002; Baker and Milligan, 2008; Dustmann and Schönberg, 2012; Carneiro, Løken, and Salvanes, 2015; Liu and Skans, 2010, Rasmussen, 2010; Dahl et al., 2015). Parental leave has positive effects on the medium and long-term labor market outcomes of mothers as well. Cash benefits that encourage leave-taking do not appear to negatively affect medium-term employment outcomes, provided the benefits do not last longer than about a year (Lalive et al., 2014; Schönberg and Ludsteck, 2014). Other evidence suggests that job-protected leave rights substantially increase maternal employment rates (Ruhm, 1998; Misra, Budig, and Boeckmann, 2011).

In the U.S., the literature has largely focused on the impacts of unpaid leave, which became available at the national level after the introduction of the Family and Medical Leave Act (FMLA) in 1993. FMLA has been shown to increase leave-taking among mothers, without any 
detectable effects on later employment (Waldfogel, 1999; Han, Ruhm, and Waldfogel, 2009). Yet because of the strict eligibility requirements, less than 60 percent of private sector workers are eligible for FMLA (Klerman et al., 2012), and the impacts of the law are concentrated among relatively advantaged women, who are more likely to be eligible and able to afford unpaid time off work.

Prior to the introduction of CA-PFL, the only legislation that offered paid leave existed through the Temporary Disability Insurance (TDI) system in five U.S. states (California, Hawaii, New Jersey, New York, and Rhode Island). These programs allow pregnant and post-partum women to take short leaves with pay for "pregnancy-related” disabilities. TDI only applies to new birth mothers and not to new fathers. In contrast, CA-PFL allows both mothers and fathers to take paid time off to care for their newborn or adopted children. ${ }^{3}$ Recent work shows that California's policy approximately doubles the leave-taking rates of new mothers, with the largest effects concentrated among disadvantaged groups (Rossin-Slater, Ruhm, and Waldfogel, 2013; Baum and Ruhm, 2015).

The focus of prior research on maternal leave-taking partially occurs because fathers tend to take very little time off work compared to mothers. For example, in the U.S. in 2013, 14 percent of employed mothers of children under age one reported being on leave versus less than two percent of employed fathers, and these rates have remained very stable over the past decade. ${ }^{4}$ Low rates of paternal leave-taking may reflect a lack of access to it: a 2012 report indicates that only 14 percent of U.S. employers offer paid paternity leave to most or all of their male employees (Klerman, Daley, and Pozniak, 2012). Low rates of leave-taking by fathers also make analysis of PFL more difficult, because most data sets lack sufficient numbers of fathers who are on leave to produce reliable estimates of program effects.

Our analysis focuses on California's paid leave program, which was the first of its kind in the United States. CA-PFL is gender-neutral in principle, although some features of the program may affect men and women differently. For instance, the 55 percent wage replacement rate applies only up to a maximum level, which may be more binding on new fathers than mothers, since males have higher average earnings than females. However, the maximum benefit

\footnotetext{
${ }^{3}$ California was the first of three states to introduce a paid family leave program. The other states are New Jersey (in 2008) and Rhode Island (in 2014). These states all have TDI as well, so birth mothers who are eligible for both TDI and CA-PFL have access to a total of 12 weeks of paid leave.

${ }^{4}$ These estimates come from the 2013 American Community Survey (ACS) data. The outcome refers to individuals who are employed but absent from work in the week prior to the survey date.
} 
threshold is fairly high compared to the average weekly benefit (\$1,104 versus $\$ 542$ per week in 2015), so this difference may be small. Equal treatment does not imply equal use and, in practice, a large majority of parental leave claims under CA-PFL have been made by mothers. In 2005, only 19.6 percent of all CA-PFL claims were filed by men, although by 2013, fathers were responsible for about 30 percent of claims. ${ }^{5}$

To our knowledge, only one other study has examined the effect of paid leave on fathers' leave-taking in the United States. ${ }^{6}$ Baum and Ruhm (2015) study the effects of CA-PFL on maternal and paternal leave-taking duration, using data from the National Longitudinal Survey of Youth (NLSY). They find that CA-PFL increases leave-taking by around 5 weeks for mothers, compared to two or three days for fathers. Yet an important limitation is that the NLSY has very small sample sizes - there are only 158 California fathers in the post-PFL group. Our analysis uses a much larger data set, allowing us to much more precisely estimate the effects of the paid leave program on leave-taking. In addition, because the ACS is a household survey, we are able to explore leave use patterns within households with two employed parents, including effects on joint leave-taking (by both parents) versus father-only leave-taking that occurs while mothers are at work.

\section{Data}

We use data from the 2000 Census and the 2000-2013 waves of the American Community Survey (ACS) to estimate the effects of CA-PFL on fathers' leave-taking. The ACS is conducted throughout the year and samples one percent of the population in most years; thus, it has the major advantage of providing the large samples needed to examine leave-taking behavior among fathers. ${ }^{7}$ When weighted, the ACS is a nationally-representative survey that provides information

\footnotetext{
${ }^{5}$ Statistics obtained from the California Employment Development Department. These statistics refer to bonding claims only, which pertain to those staying home with an infant under one year old. While CA-PFL also provides wage replacement benefits for individuals caring for a sick relative (spouse, child, or parent), the majority of claims filed are for bonding with an infant. About 87.5 percent of all claims are bonding claims rather than care claims. ${ }^{6}$ In related research, Han, Ruhm, and Waldfogel (2009), estimate that the unpaid leaves made available to fathers under the FMLA increased their leave-taking by an average of around two days.

${ }^{7}$ Data comes from the Integrated Public Use Microdata Series (IPUMS) database (Ruggles et al., 2010). The ACS started in 2000, and only sampled 1 -in-750 people (0.13\%). in that year. For the next four years, it was approximately a $0.5 \%$ sample of the population. The questions used in this study are very comparable in the ACS and the 2000 long-form Census. This analysis combines the 2000 ACS with the $1 \% 2000$ Census sample in order to increase the sample size in that year. We also show that our main results are robust to dropping the 2000 data.
} 
about labor market experiences and demographic factors. For our purposes, what is particularly important is that individuals are questioned about their labor market status in the week prior to the survey. The ACS does not ask about parental leave specifically, but it does identify individuals who are temporarily absent from work during some portion of the week. ${ }^{8}$ The main dependent variable that we examine below is whether the father (or mother) is on leave from work in the reference week. This absence could be for many reasons including parental leave, vacation, or illness. ${ }^{9}$ Unfortunately the survey does not inquire about length of the temporary work absence, so we do not know whether it lasted the entire week or just some portion of it (or whether the leave began in an earlier week).

In addition to not observing parental leave specifically, there are two other important limitations of the ACS data. First, fathers can only be linked to children who live in the same household. The analysis therefore excludes an important group of fathers who do not live with their children. Assuming that these fathers are less involved with their children than those who live with them, our results will overstate the increase in leave-taking for the average new father (including those not residing with their infants). Second, the ACS lacks precise information on children's birth dates, and only reports the age of the child in years. Although CA-PFL can be used at any time in the first 12 months of the child's life, most fathers take only brief leaves that occur soon after the birth (Baum and Ruhm, 2015). Since we observe leave-taking in only a single week, we will therefore miss most of these leaves. ${ }^{10}$ However, under the assumptions that births and the average length of leave are both uniformly distributed throughout the year, the percentage change in leave-taking estimated to result from the policy will be accurately captured, although the levels will be understated. ${ }^{11}$

\footnotetext{
${ }^{8}$ Another limitation is that the ACS does not distinguish between paid and unpaid leave.

${ }^{9}$ Specifically, the question asked is: "LAST WEEK, was this person TEMPORARILY absent from a job or business?” Respondents can answer "Yes, on vacation, temporary illness, labor dispute, etc.” or "No.” The Current Population Survey (CPS) asks about maternity/paternity leave specifically and is used to identify the effect of CAPFL on mothers' leave-taking in Rossin-Slater, Ruhm, and Waldfogel (2013). However, the sample of fathers on leave in California in the CPS is too small to produce meaningful estimates.

${ }^{10}$ Both of these limitations also apply to mothers, but to a lesser extent, since most children in single parent households live with mothers, and mothers typically take much longer leaves than fathers.

${ }^{11}$ We checked the validity of the assumption that births are uniformly distributed throughout the year in the U.S. individual-level birth records data from 2011. Although there is some variation in the number of births by month, the differences are not very large. The month with the lowest number of births was February, which accounted for 7.5 percent of all births in 2011. Of course this is not surprising given that February has the fewest days. April had the second lowest number of births, accounting for 7.9 percent of all 2011 births. The month with the highest number of births was August, which accounted for 9.1 percent of all births in 2011. Unfortunately, the ACS does not
} 
The analysis sample is limited to fathers who are 16-54 years old and employed in the survey reference week. We condition on employment because those who are not employed are less likely to be eligible for paid family leave and because we will not observe them as leave-takers in the ACS. ${ }^{12}$ However, we show in Section VI that the results are robust to including all fathers in the analysis, regardless of employment status. We also demonstrate that CA-PFL does not affect the probability that fathers of infants are employed, which is unsurprising given the short amount of paid leave available. We do not observe CA-PFL eligibility status directly, and so our estimation procedure treats all employed fathers in California as eligible for paid leave if their youngest own child in the household is less than one year old. To the extent this assumption is incorrect, we will understate the increases in leave-taking occurring for eligible fathers.

The first five columns of Appendix Table A1 report summary statistics for the sample of fathers used in our preferred empirical specification, which compares employed fathers of infants less than one year old to employed fathers of youngest children aged one to three, in California versus corresponding fathers in other states. For comparison, we also report the same summary statistics for employed mothers in the subsequent five columns. All statistics are weighted by the ACS person weights. There are several important differences between parents of infants in California and parents of infants in other states. Most notably, California parents are more likely to be Hispanic and less likely to be non-Hispanic white. Additionally, a substantially higher fraction have less than a high school education and are not citizens, although mean household income (in 2010 dollars) is somewhat higher. Finally, parents of infants in California are more likely to be on leave than those in other states, suggesting that CA-PFL may have had an effect on leave-taking.

Figure 1 plots the percentage of fathers with infants on leave in California versus all other states. After CA-PFL is implemented, there is a large increase in leave-taking in California relative to elsewhere in the U.S. in most years. ${ }^{13}$ We explore this relationship further using regression models.

contain information about the month of the survey, so we cannot measure the timing of leave relative to birth even under these assumptions.

${ }^{12}$ Some non-employed fathers, who previously worked, may be eligible for CA-PFL benefits because the work history requirements for receiving it are so weak. However, we will not observe this in our data since such men will not be classified as being temporarily absent from work.

${ }^{13}$ One of the reasons for the national downward trend in fathers' leave-taking starting in 2008 may be the recent recession. Leave-taking is negatively correlated with the unemployment rate, and workers may be more hesitant to request time off when the labor market is weak. In 2013, at the end of our sample period, the national unemployment 


\section{Empirical Strategy}

To identify the impact of CA-PFL on fathers' leave-taking behavior, we begin with a difference-in-differences (DD) framework, comparing leave-taking rates among fathers of infants in California before and after the implementation of CA-PFL to the same difference for a comparison group of either California fathers with slightly older children, who are not expected to be affected by the policy, ${ }^{14}$ or fathers of infants in other states. Specifically, we estimate:

(1) $Y_{\text {ist }}=\beta_{0}+\beta_{1}$ Treat $_{\text {ist }}+\beta_{2}$ Treat $_{\text {ist }} *$ Post $_{t}+\gamma^{\prime} X_{\text {ist }}+\rho^{\prime} C_{s t}+\delta_{s}+\phi_{t}+\varepsilon_{i s t}$

where the outcome $Y_{i s t}$ is an indicator equal to one if individual $i$ living in state $s$ who is surveyed in year $t$ is on leave from work in the reference week and zero otherwise. The dummy variable Treat ${ }_{i s t}$ is equal to one for California fathers of infants and Post $_{t}$ is an indicator equal to one if the individual is surveyed in 2005 or later. ${ }^{15}$ The vector $X_{\text {ist }}$ contains the following individual-level indicator variables: father's age in bins (<20, 20-24, 25-29, 30-34, 35-39, 40-44, 45-49, 50-54), race/ethnicity (non-Hispanic white, black, Hispanic, Asian, other race), education categories (less than high school, high school, some college, 4-year degree or more), marital status, citizenship status, the age of the youngest child in the household in years, and the total number of children in the household. We also include the following state-year controls in vector $C_{s t}$ to account for labor market conditions and other state-specific factors affecting the decision to work: unemployment rate, average welfare benefit for a four-person family, poverty rate, state minimum wage, per capita income, the log of the population, and an indicator for whether or not

rate was still substantially above the pre-recession level, which explains part of this decline. DD regression results below control for state-level economic conditions. Our preferred DDD specification includes state by year interactions to account for differential impacts of the Great Recession across states.

${ }^{14}$ Some California fathers with older children could take leave under the program since it also covers time off to care for sick relatives (or one's own illness). To the extent this occurs, we may slightly understate the induced increase in leave-taking.

${ }^{15}$ CA-PFL started paying out benefits in July 2004. As mentioned, only the survey year (not month) can be identified in the ACS and the exact birthdates of children are unknown. Because of these issues, a reported infant in 2004 may have been born as early as January 2013. Back of the envelope calculations suggest that only about 10 percent of California fathers with infants surveyed in 2004 would have been born after the implementation of CAPFL, compared with 87.5 percent of fathers surveyed in 2005. Therefore, we treat 2005 as the first year of the policy. 
the governor is Democratic. ${ }^{16}$ State and year fixed effects are captured by $\delta_{s}$ and $\phi_{t}$, respectively, with the Post $t_{t}$ main effect being subsumed into the time fixed effects. The coefficient of interest, $\beta_{2}$, is the DD estimate of the effect of CA-PFL on fathers' leave-taking in California. We estimate (1) as a linear probability model, but results are very similar when instead estimating a probit model. These results are available upon request.

The DD estimate in (1) will be biased if trends in leave-taking rates between the treatment and control groups would have been different in the absence of CA-PFL. Although this assumption is fundamentally untestable, we explore the robustness of our results to the use of several alternative comparison groups. First, we compare California fathers of infants to corresponding fathers in other states. ${ }^{17}$ Because paternity leave is not specifically observed in the ACS data, the key identification assumption of common trends in leave-taking for fathers of infants in California and in other states (in the absence of the policy) could be violated if there are differential changes in the rate of types of leave-taking that are unrelated to CA-PFL (e.g., vacation or sick days). As long as any such changes are not specific to fathers of infants, this concern can be addressed by instead comparing California fathers of infants to California fathers of youngest children aged 1-3 (or 2-4) at the survey date. ${ }^{18}$ Fathers of older children in California are not eligible to receive paternity leave benefits under CA-PFL, and therefore will serve as a second control group. Interpreting the resulting treatment effect as causal requires the assumption that rates of leave-taking in California are not differentially changing among fathers of infants and of slightly older children for reasons unrelated to CA-PFL.

These two sets of control groups can be combined into a difference-in-difference-indifferences (DDD) model that compares fathers with infants to fathers of older children, in California versus other states, before and after the policy. This DDD specification allows for differential trends in leave-taking across states and by age of youngest child as long as the difference in the rate of change between fathers of infants and older children in California would

\footnotetext{
${ }^{16}$ The state-year controls come from the University of Kentucky Poverty Research Center National Welfare Data.

${ }^{17}$ Individuals from New Jersey are excluded from the analysis because the state implemented its own PFL policy in 2008. Ideally we would use New Jersey as another treatment state. However, sample sizes of fathers on leave in New Jersey are too small (between 4 and 20 per year on leave) to produce meaningful estimates. Rhode Island is the only other state to have also started a PFL program, but it did so in 2014, after our sample ends.

${ }^{18}$ State-year controls and state fixed effects are omitted from (1) when using fathers in California with older children as the control group. Robust standard errors are used when making comparisons within California. Standard errors are clustered at the state level in models comparing fathers in California to those in other states. In additional specifications, we also show that our results are robust to using the Donald and Lang (2007) method to calculate standard errors.
} 
have been the same as that in other states in the absence of CA-PFL. Under this assumption, we estimate the DDD equation:

(2) $Y_{\text {ist }}=\beta_{0}+\beta_{1}$ Under $_{1 i s t}+\beta_{2} C A_{s} *$ Post $_{t}+\beta_{3} C A_{s} *$ Under $1_{\text {ist }}+\beta_{4}$ Post $_{t} *$ Under $1_{i s t}+\beta_{5} C A_{s} *$ Post $_{t} *$ Under $1_{i s t}+\gamma^{\prime} X_{i s t}+\delta_{s}+\phi_{t}+\theta_{s t}+\varepsilon_{i s t}$

where $Y_{i s t}$, Post $_{t}, X_{\text {ist }}, \delta_{s}$ and $\phi_{t}$ are as above, Under 1 is an indicator equal to 1 if the individual's youngest child is less than one year old and zero otherwise, and $C A_{s}$ is an indicator for the respondent residing in California. The DDD model also allows for the estimation of state by year fixed effects $\left(\theta_{s t}\right)$, which replace the state-year controls. The fixed effects make it unnecessary to include the main effects of $C A_{s}$ and Post $_{t}$ explicitly in the model, and the DDD coefficient is $\beta_{5}$. This coefficient represents the effect of CA-PFL on paternity leave among fathers of infants in California. Although the outcome variable captures work absences overall and not just paternity leave, there is no reason to think that CA-PFL would differentially impact work absences for other purposes among fathers of infants.

To interpret the DDD effect as the causal effect of CA-PFL on fathers' leave-taking, the implementation of the policy must be uncorrelated with other time-varying determinants of leave-taking in our sample of employed fathers of young children. This assumption would be violated if the CA-PFL law induced selection into our sample through impacts on fathers' employment or fertility patterns. Moreover, since we can only observe fathers who reside with their children in our data, we also face a threat to our identification assumption if the policy influenced father-child cohabitation rates or was correlated with differential migration into or out of California.

To evaluate the plausibility of these concerns, Table 1 presents results from regressions that estimate the DDD model (equation (2)) using observable paternal characteristics as dependent variables (and omitting the controls in $X_{i s t}$ ). Since we do not include individual-level controls in these specifications, we collapse the data to the father-group/state/year level, where father-group denotes whether the father has an infant or a child aged 1-3. 
The results in columns (1) and (2) of Table 1 show that CA-PFL does not either significantly or materially affect employment status or the probability of having an infant in the household. ${ }^{19}$ For example, the 95 percent confidence interval of the employment effect is -0.6 to 0.9 percentage points, compared to a baseline average of $89.9 \%$. Given the relatively modest benefit available (up to 55 percent of wages for up to six weeks), this finding is not surprising. We also show that the policy is uncorrelated with other paternal demographic characteristics, including marital status, education (except the share of fathers with some college education, which is marginally significant at the $10 \%$ level), share of fathers who are non-Hispanic white, and share of fathers who are from an under-represented minority (URM) group, which includes blacks, Hispanics, and other non-white, non-Asian races. ${ }^{20}$ We do find that fathers of infants in California post-PFL are slightly younger than fathers in the comparison groups. However, the effect is small and, since the rate of leave-taking is increasing in father's age, this correlation suggests that the observed positive effects on leave-taking are, if anything, slightly underestimated. Finally, in the last column, we show results when "predicted leave-taking"generated using a large set of fathers' demographic characteristics and their interactions-serves as the outcome. ${ }^{21}$ These findings suggest that CA-PFL is uncorrelated with paternal demographics that predict leave-taking behavior. It is therefore unlikely that differential demographic trends among fathers of infants in California drive the results shown in the next section.

\section{Results}

Table 2 shows the estimated effect of CA-PFL on parents' leave-taking behavior in California. The first six columns show results for fathers, for each of the models described

\footnotetext{
${ }^{19}$ The regression in column (2) of Table 1 is based on a DD model, which compares all fathers of children age 3 and younger in California to all fathers of the same age children in other states, before and after CA-PFL implementation. All other columns report estimates from DDD models.

${ }^{20}$ In supplementary analyses, we found small but significant correlations between the law and the share of employed fathers of infants who are black (positive) or Hispanic (negative). These correlations may be spurious due to the small sample size of employed black fathers with an infant in the household in our data. Or they could reflect coincident trends in father-child cohabitation rates that are different across races. However, analysis of the effects of CA-PFL by race suggest that these correlations go in the wrong direction to explain our results.

${ }^{21}$ Specifically, we use the underlying individual-level data to regress leave-taking rates on paternal demographic controls for: age of youngest child, marital and citizenship status, fathers' age, and race and education, and all raceeducation interactions. We then use the predicted values from this regression as a "summary index" of selection.
} 
above. The first three columns show the DD estimates using a control group of fathers of infants in all other states, and control groups of fathers of 1-3 and 2-4 year olds in California, respectively. ${ }^{22}$ The last column shows DDD results for mothers using our preferred specification.

The DD coefficients in columns (1)-(3) suggest that CA-PFL leads to a 0.88-1.25 percentage point increase in fathers' leave-taking, representing a 44 to 63 percent increase from the pretreatment mean of 1.99 percent. Figures 2 and 3 show the corresponding event-study plots for the models using fathers of infants in other states and fathers of 1-3 year olds in California as control groups, with the coefficients normalized to zero in 2004. Although the estimates are somewhat noisy, there is no evidence of an upward trend in leave-taking among fathers of infants in California, relative to the control group, prior to the introduction of CA-PFL. However, there is an indication of an upward trend after the policy takes effect. Such an increase over time (rather than an immediate jump) might occur if fathers are learning about the availability of CA-PFL, and this is consistent with the 146 percent increase in male "bonding" claims (from 24,021 to 59,256) filed in California between 2005 and the 2012-2013 fiscal year. ${ }^{23}$

Our preferred DDD specification, shown in column (4) of Table 2, suggests that the policy causes a 0.9 percentage point, or 46 percent, increase in leave-taking from the pre-treatment baseline of 1.99 percent. This model compares fathers of infants to fathers of youngest children aged 1-3, in California versus other states, before and after the introduction of the policy. Results are very similar if fathers of youngest children aged 2-4 are used instead, and therefore are not shown. Columns (5) and (6) of Table 2 show that the DDD results are robust to the inclusion of state-specific linear time trends and the exclusion of state-year fixed effects. Since the DDD model allows for both national trends in leave-taking among fathers with infants, as well as statespecific trends in leave-taking overall, subsequent results are only presented for the DDD model. However, results from the DD models are similar.

We cannot directly translate the estimated PFL program effects into the number of additional days of leave taken, because the ACS contains only binary information about temporary absences from work during the prior week, not information about the total amount of time off

\footnotetext{
${ }^{22}$ We present results with fathers of 2-4 year olds as the control group because infant age could be misreported if parents state that they are one year old instead of less than one. The data suggest that this is not an issue. In the sample of fathers with youngest children 0-3 in California, 28.04 percent have an infant less than one year old and 27.18 percent report having a one year old.

${ }^{23}$ CA-PFL program statistics were obtained from the State of California Employment Development Department. See http://www.edd.ca.gov/About_EDD/Quick_Statistics.htm for more information. Bonding claims are for taking leave to stay home with an infant rather than to provide care for a sick relative.
} 
during that week. However, if we assume that these men were off the job for the full week and births of infants were uniformly distributed throughout the year, our preferred estimates suggest that the program added approximately 2.4 days of leave ( 0.00915 x 52 weeks x 5 days/week) from a pre-treatment baseline of around 5.2 days.

The last column of Table 2 shows the effect of CA-PFL on maternal leave-taking behavior using our preferred DDD specification. ${ }^{24}$ Similar to Rossin-Slater, Ruhm, and Waldfogel (2013) and Baum and Ruhm (2015), we find that mothers are also more likely to take leave after the introduction of CA-PFL. CA-PFL leads to a 2.3 percentage point increase in leave-taking among mothers with infants, which represents a 13 percent increase from the pre-treatment baseline. In percentage terms, this is much smaller than the effect estimated for men (13 vs. 46 percent) but it is much larger in absolute terms, since new mothers are more likely to be on leave. Assuming that temporary work absences last for the full reference week, CA-PFL is estimated to increase the leave-taking of new mothers by 6 days from a base level of around 46 days.

Because CA-PFL provides paid parental leave to any eligible parent and not just the primary caregiver, Table 3 explores effects on joint leave-taking by employed parents in the household. The sample in this analysis is limited to fathers with employed spouses, so that both parents are working and potentially eligible to take paid leave, and demographic controls for both spouses are included in the regressions. ${ }^{25}$ As expected, the program has large effects on both mothers and fathers. Column (1) shows that the policy increases leave-taking by either parent by four percentage points, or 22 percent. The increase in fathers' leave-taking is driven both by a 0.41 percentage point rise in the probability that both parents are on leave at the same time (a 28 percent increase) and a 0.53 percentage point increase in father-only leave, while the mother is at work (a 50 percent increase). The increase in father-only leave-taking means that providing CAPFL to fathers - in addition to mothers - increases the total number of days that at least one parent stays home with the infant. Married employed mothers are substantially more likely to take leave after the CA-PFL program comes into effect as well, and they are almost always on leave while the father is at work.

\footnotetext{
${ }^{24}$ Appendix Table A2 shows all columns of Table 2 for mothers instead of fathers.

${ }^{25}$ The sample is essentially the same if we condition on the mother and father of the youngest child residing in the same household (but not necessarily being married). This is a function of how IPUMS links children to parents: if both parents are present but not married to each other, the least proximate parent is unlinked. We do not distinguish between stepmothers and biological mothers.
} 


\section{Heterogeneity}

There is substantial heterogeneity in both fathers' and mothers' leave-taking behavior depending on their child's gender and birth order. Table 4 shows that fathers of sons are much more likely to take paternity leave after CA-PFL than fathers of daughters. Column (1) suggests that the overall effect of the policy is about 50 percent larger for fathers of sons than for those of daughters. When the sample is limited to fathers married to employed mothers (columns 3-6), these gender effects become even stronger-fathers of girls do not respond to the policy at all, but the effects are large for fathers of boys. Column 4 shows that CA-PFL increases joint leavetaking by 58 percent ( 0.83 percentage points) if the infant is male but does not increase joint leave-taking at all for parents of baby girls. The policy similarly increases the likelihood that married fathers with sons are on leave by themselves by 97 percent (1 percentage point) but again has no effect on fathers of girls. The finding that fathers are more likely to spend time at home with sons than daughters is consistent with similar evidence on paternal son-preference with regard to marriage and divorce (Bedard and Deschênes, 2005; Lundberg and Rose, 2003; Lundberg, McLanahan, and Rose, 2007; Dahl and Moretti, 2008) as well as paternity acknowledgement (Almond and Rossin-Slater, 2013). ${ }^{26}$ There are at least two explanations for this type of son preference. First, it may be that fathers get more utility from spending time with their sons than daughters. Second, it may be that the parents perceive that paternal time spent caring for boys is relatively more productive than time spent caring for girls. While we cannot distinguish between these two channels in our data, the latter explanation seems less plausible given that it is unlikely that fathers have a relative advantage in caring for boys around the time of birth.

Interestingly, the opposite appears to be true among mothers. Column (2) of Table 4 shows that the policy has a larger effect on mothers of daughters than it does on those with sons. Conditional on both parents working, married mothers are 44 percent more likely to take leave by themselves if the child is female, although this result (column 6) is only weakly significant. Finally, column (3) shows that there is not a significant difference in the probability that either parent is on leave for boys relative to girls.

\footnotetext{
${ }^{26}$ In related work, Lundberg and Rose (2002) find that fathers' labor supply and wages increase more in response to births of sons than births of daughters, which is in contrast to our finding that fathers spend more time at home with newborn boys than girls. However, they study data from the Panel Study of Income Dynamics (PSID) covering the years 1968-1992, which is a time period with very little availability of paid family leave for men in the U.S.
} 
Table 5 shows that birth order also matters for fathers' but not mothers' leave-taking. Specifically, fathers are much more likely to use CA-PFL after the birth of their first child than after a subsequent birth. Column (1) of Table 5 indicates that the policy increases leave-taking after first births by almost two percentage points, or 96 percent. However, after second or higherorder births, the effect is only 0.35 percentage points (18 percent). This finding is interesting, in part, because it cannot be explained by differences in information about the policy. In supplementary analyses, we found no differences in the effect on leave-taking for the second or higher birth depending on whether the first child was born before or after the policy. The prepolicy mean rates of leave-taking are not significantly different by birth order, so this difference is not driven by pre-existing patterns either. Interestingly, the birth order difference in the effects of CA-PFL is unique to fathers: there is no corresponding significant birth order difference in the DDD effects of the policy when looking at the probability that the mother is on leave, or within two-parent households where both parents work, on the probability that either parent is on leave or the mother only is on leave. Moreover, the effect on the probability of father-only leave while the mother is at work is driven entirely by first births, as is the effect on the probability that both parents are on leave. There are several possible explanations for the relatively stronger effect of CA-PFL on leave-taking after first births. Mothers may need the most help caring for their firstborn child, so having the father at home may be especially beneficial. However, if this were the sole explanation, we would not expect to see the increase in father-only leave-taking driven by first births as well. An alternative theory is that fathers want to be more involved with the care of their first child, but revert back to more traditional gender roles over time. Finally, because CAPFL does not include job protection during leave, employers may be more willing to let firsttime fathers take time off work.

Additional analysis of the effects of CA-PFL allowing for both child gender and birth order interactions suggests that fathers are more likely to take leave after a first birth than a subsequent birth regardless of child's gender. In fact, there is no statistically significant difference in fathers' leave-taking among first children based on the gender of the child. The gender effect is driven by the fact that fathers are significantly more likely to take leave after second and higher parity births if the infant is male compared to female. This suggests that the gender results are not driven by factors such as systematic differences in infant health, because if they were, the gender differential should hold across child parity. 
The effect of CA-PFL on leave-taking behavior also varies by occupation. In Table 6, we categorize occupations into those with a high share of female workers (above the median) and those with a low share of female workers, based on the 2000 Census. The effects of CA-PFL are stronger for fathers in occupations with more female workers. This pattern is even more apparent for mothers, where there are only significant effects of CA-PFL in high female share occupations. While one possible explanation for this pattern is that people sort into occupations based on family-friendliness (and women value this more on average), another is that taking parental leave becomes more socially acceptable as more people use it. When there are more mothers taking leave in a given occupation, it may be easier for fathers to do the same. ${ }^{27}$

Finally, we also explored heterogeneity in leave-taking by fathers' demographic characteristics. We obtain suggestive evidence that the effects are largest among non-Hispanic white, African-American, and Asian fathers relative to Hispanic fathers, although small sample sizes prevent us from making more definitive conclusions. ${ }^{28}$ Consistent with the occupation results which show the largest effects outside the top-earning occupations, CA-PFL has a larger effect on fathers with some college or a high school degree than for those with a four year degree. However, there is no positive effect for fathers who have not graduated from high school. These results are available upon request.

\section{Robustness}

An important limitation of a difference-in-difference analysis is that one must rely on an assumption that the outcomes in treatment and control groups would have followed parallel trends in the absence of the policy reform. While this assumption is inherently untestable, the fact that our results are very consistent across the DD and DDD specifications and robust to different sets of controls is reassuring. We also perform a variety of other robustness tests that lend credibility to the identifying assumption.

\footnotetext{
${ }^{27}$ Within-household sample results (available upon request) show similar patterns in households where both parents work. The effect of CA-PFL on the probability that either parent is on leave does not differ by the share of female workers in the father's occupation, but is larger for households in which the mother has a high female share occupation. Similarly, the effect on the probability of mother-only leave depends only on the occupation of the mother, not the father, and the reverse is true for father-only leave-taking.

${ }^{28}$ Small sample sizes arise in part because we require the fathers in our sample to be employed and residing with their children. For example, there are only 49 black fathers of infants on leave in California in the whole sample, and only 1000 black fathers of infants in California overall.
} 
Table 7 shows that the findings are similar if the data are collapsed down to the state-year level or if control groups are chosen to best match pre-policy trends in fathers' leave-taking using synthetic control methods (Abadie, Diamond, and Hainmueller, 2010). The first column shows the DD estimate of the effect of the policy on the share of fathers of infants on leave in California compared to all other states. The Donald and Lang (2007) two-step approach is used to obtain the estimates and standard errors, so inference is conducted using a t-distribution with 12 degrees of freedom. The effect is very similar to the estimate obtained using individual-level data, with CA-PFL predicted to raise paternal leave taking by 0.8 percentage points in both cases. The Donald and Lang approach for calculating standard errors is often used to conduct inference when there are a small number of clusters. While 50 clusters is normally assumed to be large enough for the asymptotic results of cluster-robust standard errors to apply, recent work shows that the "effective" number of clusters is smaller when the number of observations per cluster varies across groups, as is true in the uncollapsed data (Carter, Schnepel, and Steigerwald, 2015), so that the cluster-robust standard errors could be under-estimated. However, the fact that inference is the same using the Donald and Lang two-step approach and when using clusterrobust standard errors on the uncollapsed data suggests this is not a major issue. ${ }^{29}$

The remaining columns of Table 7 show the DD effect when comparing California to synthetic control groups that may better match pre-policy trends in leave-taking. In each column, the synthetic control group is formed by matching on different combinations of state-year characteristics, and the treatment effect is obtained by regressing differences in the rate of leavetaking between California and the synthetic control group in each year on an indicator for years after the policy takes effect. The effect sizes are similar across columns, and statistically significant (at the 5 percent level) in all but one case, suggesting that the results are not sensitive to the choice of control groups.

\footnotetext{
${ }^{29}$ For more discussion of issues with standard errors in DD estimates, see Bertrand, Duflo, and Mullainathan (2004).The same potential issue with clustered standard errors applies to the DDD results. However, our results are precise enough that standard corrections for a small number of clusters do not affect inference. For instance, the point estimate in Column (4) of Table 3 is nine times larger than the standard error, so that the standard error would need to be overestimated by a factor of almost five to change inference at the 5 percent significance level. Applying a version of the Donald and Lang approach for the triple difference case yields similar conclusions for our main results. However, because consistency under this method relies on the assumption of equal group sizes and collapsing the data leads to estimates that are not population-representative, this is not our preferred approach. We also calculated standard errors using the wild bootstrap, which is another common approach to correcting for a small number of clusters. However, MacKinnon and Webb (2015) show that when the proportion of treated clusters is close to one or zero ( 0.02 in our case), the wild bootstrap tends to severely under-reject.
} 
Appendix Table A3 replicates the main results in Table 2 omitting the individual and stateyear controls and dropping year 2000 from the analysis. The similarity of the results with and without controls suggests that they are not driven by correlations with changing demographic trends. Because the majority of data in 2000 comes from the Census, instead of the ACS, one may be concerned about comparability between 2000 and the other years. In particular, the Census data is collected over a relatively short time span whereas the ACS is conducted throughout the year. If there are differences in leave-taking behavior across different parts of the year, this could potentially be a problem. However, the results are robust to both of these changes.

Because only fathers with some recent work experience are eligible for CA-PFL, all of our results condition on employment. However, the work history requirements are actually quite weak and some non-employed fathers could qualify for paid leave benefits. With this in mind, Appendix Table A4 shows that the findings are robust to relaxing this employment restriction. Specifically, the results in Table 2 hold if all fathers who have worked any positive number of weeks in the previous 12 months are included in the sample, or if all fathers with age-eligible children are included in the sample, regardless of employment status. This latter specification should be expected to attenuate the results slightly, as a smaller fraction of the treated sample is eligible for leave. However, given the high employment rate among fathers, the samples do not change dramatically, and estimated CA-PFL effects remain substantial, although slightly smaller on average than previously. ${ }^{30}$

\section{Conclusion}

While paid parental leave programs have traditionally focused on mothers, there are potential benefits to having fathers, as well as mothers, take time off work shortly after the birth of a new infant (Haas, 1990; Nepomnyaschy and Waldfogel, 2007; Tanaka and Waldfogel, 2007; Haas and Hwang, 2008). California's paid family leave program is the first source of governmentprovided paid parental leave available to fathers in the United States, and our results show that

\footnotetext{
${ }^{30}$ Additionally, results are robust to including only private sector (those not working for local, state, or federal government, or the military) in the analysis. Essentially all private sector workers are eligible for CA-PFL, but not all government employees participate in the program (although some do). As some government employees are not eligible, excluding them from the analysis increases the magnitude of the estimates slightly, but the results are very similar to those presented here (and are available upon request).
} 
the policy raised fathers' estimated leave-taking during the first year of a child's life by a substantial and statistically significant 46 percent. In relative terms, this increase is much larger than the 13 percent increase estimated for mothers, although since mothers take so much more leave, the absolute increase is only about 40 percent as large (at around two days). Interestingly, the predicted increase in male leave-taking is similar to the estimate found in Baum and Ruhm's (2015) analysis of CA-PFL, using a much smaller sample, while the rise in mother's leave-taking is considerably smaller than that obtained by either Baum and Ruhm (2015) or Rossin-Slater, Ruhm and Waldfogel (2013). ${ }^{31}$

These results, when combined with the relative lack of employer-provided paternity leave in the United States, suggest that many new fathers respond to expanded opportunities to take paid family leave. Furthermore, among married households where both parents work, father-only leave-taking increases by a substantial 46 percent, implying that these fathers may become more actively involved in childcare, spending more time alone with their infants than they would have in the absence of the policy.

The increase in paternal leave-taking may also have important implications for addressing the gender wage gap. Although women currently make up nearly half of the United States labor force, the wage gap still persists, with full-time female workers earning 77 percent of what their male counterparts earn. ${ }^{32}$ Further, mothers have traditionally performed a disproportionate share of childcare and housework, and this disparity also persists today (Hochschild and Machung, 1989; Blair and Lichter, 1991; Bianchi, 2011; Bianchi et al., 2012). The unequal burden faced by women in the home, combined with a lack of flexibility in work schedules at most jobs, may be an important explanation for why the gender wage gap still exists despite tremendous progress in women's educational and labor market performance over the last half century (Goldin, 2014). Our results suggest that a gender-neutral PFL policy can increase the amount of time fathers of newborns spend at home-including time they spend at home while the mothers work - and may

\footnotetext{
${ }^{31}$ Since the ACS does not report reasons for temporary work absence (our measure of leave-taking), it is possible that the ACS captures less parental leave-taking than other data sets such as the NLSY (used by Baum and Ruhm) and the CPS (used by Rossin-Slater, Ruhm and Waldfogel). In light of this possibility, the estimates we present here for both fathers and mothers can arguably serve as lower bounds. Also, using the NLSY, Ruhm and Baum were able to capture increased leave-taking prior to the birth (which could occur, for example, because parents are able to use vacation time that they would have otherwise had to save until after the delivery), which they found accounted for around one week of extra leave-taking for mothers (but virtually none for fathers). This is likely to explain a portion of the smaller effect we obtained for mothers.

${ }^{32}$ See: https://www.whitehouse.gov/issues/equal-pay\#top.
} 
therefore be seen as one way to promote gender equality. Future research may explore the impacts of CA-PFL on the gender wage gap as well as time use patterns in the home.

Our results also call attention to important limitations about the extent to which policymakers can use paid parental leave programs similar to the one implemented in California to increase paternal involvement in childcare. CA-PFL almost doubles the rate of leave-taking among first parity fathers, but has almost no effect on leave-taking after higher-order births. While fathers take leave from work after the birth of their first child, they do not take advantage of the CA-PFL benefit when subsequent children are born. Moreover, fathers of boys are much more likely to take leave as a result of CA-PFL than fathers of girls. Although the reasons for these results are not yet understood, they suggest that making family-friendly policies genderneutral might not be enough to change men's long-run attitudes about gender equality, or their level of participation in household duties. In addition, these patterns may reflect joint decisions made by mothers and fathers together, if for example they feel there is less need for exclusive parental care for a second or later child, or for a girl. On the other hand, our finding that men who work in female-dominated jobs are more likely to take leave raises the possibility that attitudes existing in the workplace may play an important role and that changes in societal norms about the importance of fathers, as well as mothers, spending time at home with newborns may change behaviors.

Regardless of the longer-term implications, California's PFL policy has led to a large relative increase in leave-taking among new fathers when compared to the low pre-PFL mean. Although the average number of days spent on leave is small compared to mothers, there has been a substantial increase in the share of fathers who take at least some time off work. In fact, out of all CA-PFL "newborn-bonding" claims filed in the 2013-2014 fiscal year, one-third were filed by fathers. As more states start to adopt gender-neutral parental leave policies similar to CA-PFL, we might expect to see fathers' leave-taking become even more common. 


\section{References}

Abadie, Alberto, Alexis Diamond, and Jens Hainmueller. 2010. "Synthetic Control Methods for Comparative Case Studies: Estimating the Effect of California’s Tobacco Control Program,” Journal of the American Statistical Association, 105(490): 493-505.

Almond, Douglas, and Maya Rossin-Slater. 2013. "Paternity Acknowledgement in 2 Million Birth Records from Michigan,” PLoS ONE, 8(7): e70042.

Auman, Kerstin, Ellen Galinsky and Kenneth Matos. 2011. “The New Male Mystique,” Families and Work Institute. http://familiesandwork.org/site/research/reports/newmalemystique.pdf.

Baker, Michael, Jonathan Gruber, and Kevin Milligan. 2008. "Universal Childcare, Maternal Labor Supply, and Family Well-being,” Journal of Political Economy, 116(4): 709-745.

Baker, Michael, and Kevin Milligan. 2008. "Maternal Employment, Breastfeeding, and Health: Evidence from Maternity Leave Mandates,” Journal of Health Economics, 27(4): 871-887.

Baum, Charles L. and Christopher J. Ruhm. 2015. “The Effects of Paid Family Leave in California on Parental Leave-Taking and Labor Market Outcomes,” mimeo.

Bedard, Kelly, and Olivier Deschênes. 2005. "Sex Preferences, Marital Dissolution, and the Economic Status of Women,” Journal of Human Resources, 40(2): 411-434.

Bertrand, Marianne, Esther Duflo, and Sendhil Mullainathan. 2004. "How Much Should We Trust Differences-in-Differences Estimates?” Quarterly Journal of Economics, 119(1): 249-275.

Bianchi, Suzanne M. 2011. "Family Change and Time Allocation in American Families," The ANNALS of the American Academy of Political and Social Science, 638(1): 21-44.

Bianchi, Suzanne M, Liana C. Sayer, Melissa A. Milkie, and John P. Robinson. 2012. “Housework: Who Did, Does, or Will Do It, and How Much Does It Matter?” Social Forces, 91(1): 55-63.

Blair, Sampson Lee, and Daniel T. Lichter. 1991. "Measuring the Division of Household Labor Gender Segregation of Housework among American Couples,” Journal of Family Issues, 12(1): 91-113.

Boll, Christina, Julian Leppin, and Nora Reich. 2014. "Paternal Childcare and Parental Leave Policies: Evidence from Industrialized Countries," Review of Economics of the Household, 12(1): 129-158.

Carneiro, Pedro, Katrine V. Løken, and Kjell G. Salvanes. 2015. “A Flying Start? Maternity Leave Benefits and Long-Run Outcomes of Children,” Journal of Political Economy, 123(2): 365-412. 
Carter, Andrew V., Kevin T. Schnepel, and Douglas G. Steigerwald. 2015. “Asymptotic Behavior of a t Test Robust to Cluster Heterogeneity,” University of California, Santa Barbara, mimeo.

Dahl, Gordon B., and Enrico Moretti. 2008. "The Demand for Sons." The Review of Economic Studies, 75(4): 1085-1120.

Dahl, Gordon B., Katrine V. Løken, and Magne Mogstad. 2014. "Peer Effects in Program Participation,” American Economic Review, 104(7): 2049-2074.

Dahl, Gordon B., Katrine V. Løken, Magne Mogstad, and Kari Vea Salvanes. 2015. "What Is the Case for Paid Maternity Leave?” The Review of Economics and Statistics, forthcoming.

Donald, Stephen G., and Kevin Lang. 2007. "Inference with Difference-in-Differences and Other Panel Data," The Review of Economics and Statistics, 89(2): 221-233.

Dustmann, Christian, and Uta Schönberg. 2012. "Expansions in Maternity Leave Coverage and Children's Long-Term Outcomes,” American Economic Journal: Applied Economics, 4(3): 190224.

Duvander, Ann-Zofie, and Mats Johansson. 2012. "What are the Effects of Reforms Promoting Fathers’ Parental Leave Use?" Journal of European Social Policy, 22(3): 319-330.

Earle, Alison, Zitha Mokomane, and Jody Heymann. 2011. "International Perspectives on WorkFamily Policies: Lessons from the World's Most Competitive Economies," The Future of Children, 21(2): 191-210.

Ekberg, John, Rickard Eriksson, and Guido Friebel. 2013. "Parental Leave-A Policy Evaluation of the Swedish 'Daddy-Month’ Reform,” Journal of Public Economics, 97: 131-143.

Fitzpatrick, Maria Donovan. 2012. "Revising Our Thinking about the Relationship between Maternal Labor Supply and Preschool,” Journal of Human Resources 47(3): 583-612.

Fuwa, Makiko and Philip N. Cohen. 2007. "Housework and Social Policy," Social Science Research, 36(2): 512-530.

Goldin, Claudia. 2014. “A Grand Gender Convergence: Its Last Chapter," The American Economic Review, 104(4), 1091-1119.

Haas, Linda. 1990. "Gender Equality and Social Policy: Implications of a Study of Parental Leave in Sweden,” Journal of Family Issues, 11(4): 401-423.

Haas, Linda and C. Philip Hwang. 2008. “The Impact of Taking Parental Leave on Fathers Participation in Childcare and Relationships with Children: Lessons from Sweden," Community, Work and Family, 11(1): 85-104. 
Han, Wen-Jui, Christopher Ruhm, and Jane Waldfogel. 2009. "Parental Leave Policies and Parents' Employment and Leave-Taking,” Journal of Policy Analysis and Management 28(1): 29-54.

Havnes, Tarjei, and Magne Mogstad. 2011. "Money for Nothing? Universal Child Care and Maternal Employment,” Journal of Public Economics 95(11): 1455-1465.

Hochschild, Arlie, and Anne Machung. 1989. The Second Shift: Working Parents and the Revolution at Home, New York: Viking.

Klerman, Jacob A., Kelly Daley, and Alyssa Pozniak. 2012. Family and Medical Leave in 2012: Technical Report, prepared for the U.S. Department of Labor (Contract \#GS10FOO86K). Cambridge, MA: Abt Associates, http://www.dol.gov/asp/evaluation/fmla/FMLA-2012Technical-Report.pdf, accessed September 5, 2015.

Lalive, Rafael, Analía Schlosser, Andreas Steinhauer, and Josef Zweimüller. 2014. "Parental Leave and Mothers' Careers: The Relative Importance of Job Protection and Cash Benefits," Review of Economic Studies, 81(1): 219-265.

Lefebvre, Pierre, and Philip Merrigan. 2008. "Child-care policy and the labor supply of mothers with young children: A natural experiment from Canada." Journal of Labor Economics, 26(3): 519-548.

Liu, Qian, and Oskar Nordstrom Skans. 2010. "The Duration of Paid Parental Leave and Children's Scholastic Performance," The BE Journal of Economic Analysis \& Policy 10(1): Article 3.

Lundberg, Shelly, and Elaina Rose. 2002. "The Effects of Sons and Daughters on Men's Labor Supply and Wages," Review of Economics and Statistics 84(2): 51-268.

Lundberg, Shelly, and Elaina Rose. 2003. "Child Gender and the Transition to Marriage," Demography 40(2): 333-349.

Lundberg, Shelly, Sara McLanahan, and Elaina Rose. 2007. "Child Gender and Father Involvement in Fragile Families,” Demography, 44(1): 79-92.

MacKinnon, James G., and Matthew D. Webb. 2015. "Wild Bootstrap Inference for Wildly Different Cluster Sizes,” Queen's Economics Department Working Paper, No. 1314.

Misra, Joya, Michelle Budig, and Irene Boeckmann. 2011. "Work-Family Policies and the Effects of Children on Women's Employment Hours and Wages," Community, Work and Family, 14(2): 139-157.

Nepomnyaschy, Lenna and Jane Waldfogel. 2007. "Paternity Leave and Fathers' Involvement with Their Young Children: Evidence from the ECLS-B," Community, Work, and Family 10(4): 425-451. 
Patnaik, Ankita. 2015. "Reserving Time for Daddy: The Short and Long-Run Consequences of Fathers’ Quotas,” Available at SSRN: http://ssrn.com/abstract=2475970.

Rasmussen, Astrid Würtz. 2010. "Increasing the Length of Parents' Birth-Related Leave: The Effect on Children's Long-Term Educational Outcomes,” Labour Economics 17(1): 91-100.

Rehel, Erin and Emily Baxter. 2015. "Men, Fathers and Work-Family Balance," Center for American Progress.

https://cdn.americanprogress.org/wp-content/uploads/2015/02/MenWorkFamily-brief.pdf

Ray, Rebecca, Janet C. Gornick, and John Schmitt. 2009. "Parental Leave Policies in 21 Countries: Assessing Generosity and Gender Equality," Center for Economic and Policy Research Report. http://www.cite.gov.pt/asstscite/images/grafs11/Parent_Leave_Policies_21.pdf

Rønsen, Marit, and Marianne Sundström. 2002. "Family Policy and After-Birth Employment among New Mothers-A Comparison of Finland, Norway and Sweden." European Journal of Population, 18(2): 121-152.

Rossin-Slater, Maya, Christopher J. Ruhm, and Jane Waldfogel. 2013. "The Effects of California's Paid Family Leave Program on Mothers' Leave-Taking and Subsequent Labor Market Outcomes,” Journal of Policy Analysis and Management, 32(2): 224-245.

Ruggles, Steven J., Trent Alexander, Katie Genadek, Ronald Goeken, Matthew B. Schroeder, and Matthew Sobek. 2010. Integrated Public Use Microdata Series: Version 5.0 [Machinereadable database]. Minneapolis, MN: Minnesota Population Center [producer and distributor].

Ruhm, Christopher J. 1998. "The Consequences of Parental Leave Mandates: Lessons from Europe.” Quarterly Journal of Economics, 113(1): 285-318.

Ruhm, Christopher J. 2011. "Policies to Assist Parents with Young Children," The Future of Children, 21: 37-68.

Schober, Pia S. 2014. "Parental Leave and Domestic Work of Mothers and Fathers: A Longitudinal Study of Two Reforms in West Germany,” Journal of Social Policy, 43(2): 351372.

Schönberg, Uta and Johannes Ludsteck. 2014. "Expansions in Maternity Leave Coverage and Mothers’ Labor Market Outcomes after Childbirth,” Journal of Labor Economics, 32(3): 469505.

Tanaka, Sakiko and Jane Waldfogel. 2007. "Effects of Parental Leave and Working Hours on Fathers' Involvement with Their Babies: Evidence from the UK Millennium Cohort Study.” Community, Work, and Family, 10(4): 407-424. 
University of Kentucky Center for Poverty Research. 2014. "UKCPR National Welfare Data, 1980-2013.” Gatton College of Business \& Economics, University of Kentucky, Lexington, KY. http://www.ukcpr.org/data.

Waldfogel, Jane. 1999. “The Impact of the Family and Medical Leave Act,” Journal of Policy Analysis and Management, 18(2): 281-302.

Waldfogel, Jane. 2002. “Child Care, Women’s Employment, and Child Outcomes,” Journal of Population Economics, 15(3): 527-548.

Figure 1: Fathers' Leave-Taking in CA Compared to Other States, Youngest Child Less Than Age 1

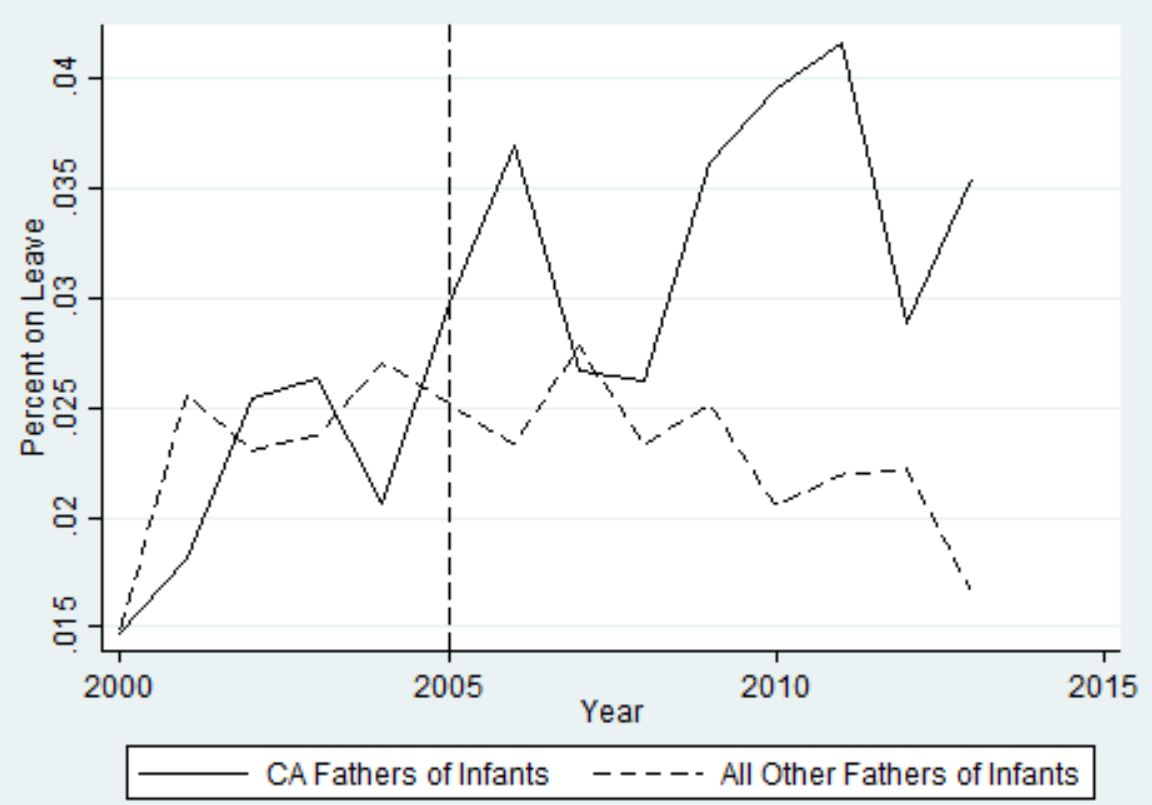

Notes: This figure plots the mean leave-taking rate for California fathers of youngest children aged less than 1 year old (in the solid line) and fathers of youngest children aged less than 1 year old in all other states (in the dashed line). 
Figure 2: Event Study Graph for Leave-Taking; Fathers of Infants in CA vs. Fathers of Infants in Other States

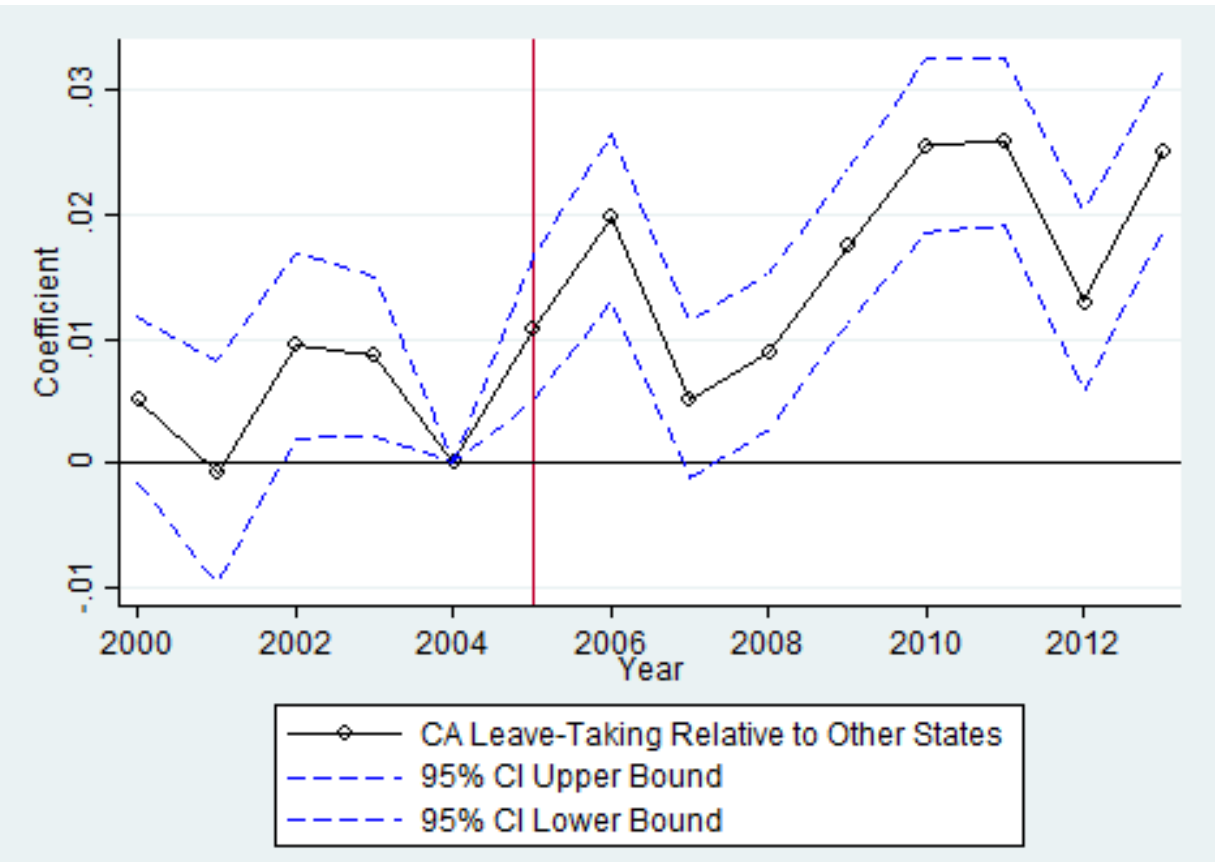

Notes: This figure plots the coefficients and 95\% confidence intervals from an event-study regression that compares the leave-taking rate of California fathers of infants relative to fathers of infants in other states in each year before and after CA-PFL implementation. The omitted category is 2004. 
Figure 3: Event Study Graph for Leave-Taking; Fathers of Infants in CA vs. Fathers of Children aged 1-3 in CA

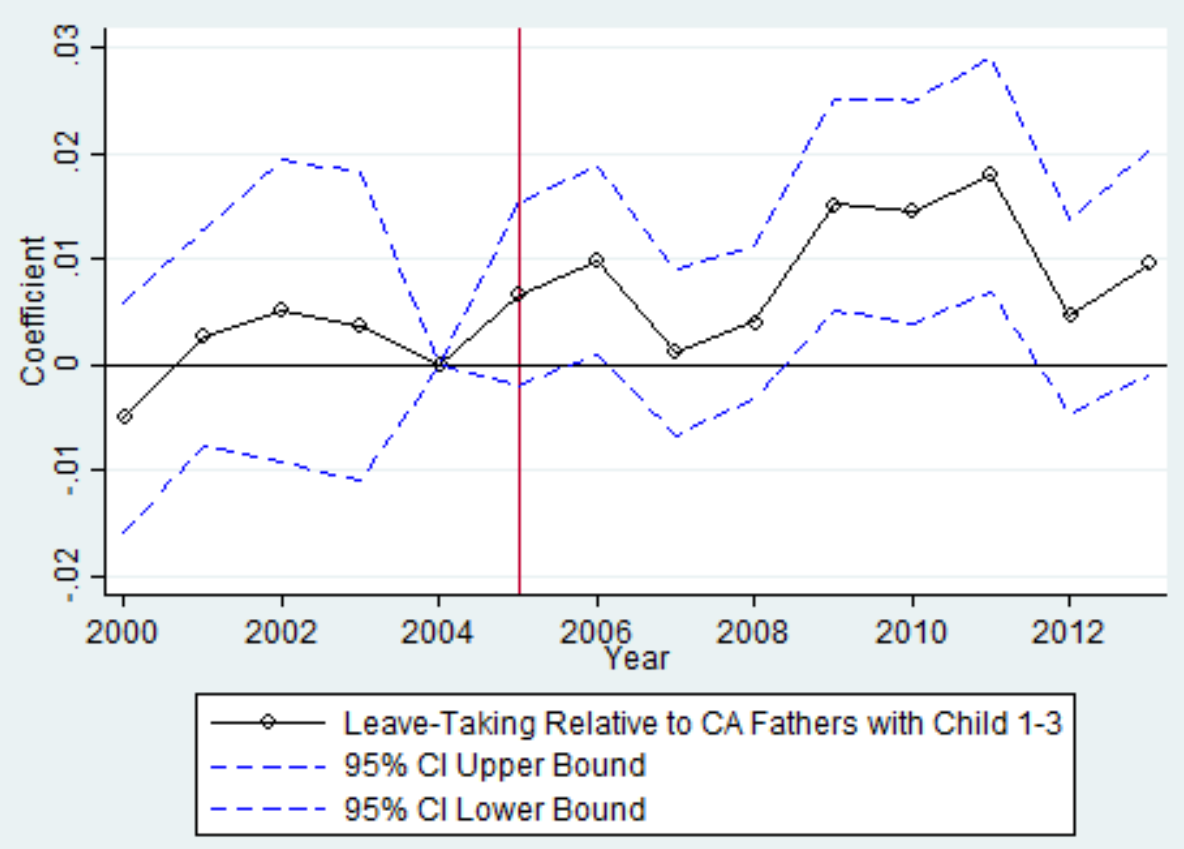

Notes: This figure plots the coefficients and 95\% confidence intervals from an event-study regression that compares the leave-taking rate of California fathers of infants relative to California fathers of youngest children aged 1-3 years old in each year before and after CA-PFL implementation. The omitted category is 2004 . 
Table 1: Correlation between CA PFL and Fathers' Characteristics

(1)

(2)

(3)

(4)

(5)

(6)

(7)

(8)

(9)

(10)

(11)

Outcome:

\begin{tabular}{|c|c|c|c|c|c|c|c|c|c|c|c|}
\hline & Employed & Has Infant & Mean age & Married & $\begin{array}{c}\text { Less than } \\
\text { High } \\
\text { School }\end{array}$ & $\begin{array}{c}\text { High } \\
\text { School }\end{array}$ & $\begin{array}{l}\text { Some } \\
\text { College }\end{array}$ & $\begin{array}{c}\text { 4-Year } \\
\text { Degree } \\
\text { or More }\end{array}$ & White & $\begin{array}{l}\text { Under- } \\
\text { represented } \\
\text { Minority }\end{array}$ & $\begin{array}{l}\text { Predicted } \\
\text { Leave }\end{array}$ \\
\hline CA*Post*Under1 & $\begin{array}{c}0.00171 \\
(0.00373)\end{array}$ & & $\begin{array}{c}-0.299 * * * \\
(0.0854)\end{array}$ & $\begin{array}{l}-0.00133 \\
(0.00396)\end{array}$ & $\begin{array}{c}-0.000541 \\
(0.00467)\end{array}$ & $\begin{array}{l}-0.00236 \\
(0.00810)\end{array}$ & $\begin{array}{c}0.0125^{*} \\
(0.00744)\end{array}$ & $\begin{array}{l}-0.00961 \\
(0.00685)\end{array}$ & $\begin{array}{l}-0.00534 \\
(0.00413)\end{array}$ & $\begin{array}{l}-0.00294 \\
(0.00487)\end{array}$ & $\begin{array}{l}-0.00166 \\
(0.00366)\end{array}$ \\
\hline CA*Post & & $\begin{array}{c}-0.000622 \\
(0.00204)\end{array}$ & & & & & & & & & \\
\hline Observations & 1,400 & 700 & 1,400 & 1,400 & 1,400 & 1,400 & 1,400 & 1,400 & 1,400 & 1,400 & 1,400 \\
\hline $\begin{array}{l}\text { R-squared } \\
\text { Individual }\end{array}$ & 0.685 & 0.288 & 0.937 & 0.700 & 0.844 & 0.786 & 0.795 & 0.882 & 0.978 & 0.969 & 0.718 \\
\hline $\begin{array}{l}\text { Controls } \\
\text { State-Year }\end{array}$ & NO & NO & NO & NO & NO & NO & NO & NO & NO & NO & NO \\
\hline Controls & NO & NO & NO & NO & NO & NO & NO & NO & NO & NO & NO \\
\hline Time FE & YES & YES & YES & YES & YES & YES & YES & YES & YES & YES & YES \\
\hline State FE & YES & YES & YES & YES & YES & YES & YES & YES & YES & YES & YES \\
\hline State-Year FE & YES & NO & YES & YES & YES & YES & YES & YES & YES & YES & YES \\
\hline Mean & 0.899 & 0.290 & 32.75 & 0.890 & 0.123 & 0.259 & 0.295 & 0.323 & 0.720 & 0.230 & 0.121 \\
\hline
\end{tabular}

Notes: Cluster robust standard errors in parentheses. Outcomes are shown in column headings. Data is collapsed by state, year, and whether or not the father has a child under 1. Regressions in columns (1) and (3)-(11) identify correlation between CA-PFL and the outcome shown, comparing fathers of infants to father with a youngest child 1-3 years old, in California versus other states, before and after the implementation of CA-PFL. Column (2) compares fathers in California to fathers in other states, before and after the policy. Columns (2)-(11) condition on the father being employed. Coefficient of interest (DDD or DD in column 2) is shown.

$* * * \mathrm{p}<0.01, * * \mathrm{p}<0.05, * \mathrm{p}<0.1$ 
Table 2: Effects of CA-PFL on Fathers' Leave-Taking Behavior

\begin{tabular}{|c|c|c|c|c|c|c|c|}
\hline & $(1)$ & $(2)$ & (3) & (4) & $(5)$ & (6) & $(7)$ \\
\hline & \multicolumn{7}{|c|}{ All Parents Sample } \\
\hline & \multicolumn{6}{|c|}{ Father is on leave } & $\begin{array}{l}\text { Mother is } \\
\text { on Leave }\end{array}$ \\
\hline & DD State & DD $1-3$ & DD 2-4 & DDD 1-3 & DDD 1-3 & DDD 1-3 & DDD 1-3 \\
\hline CA*Post*Under1 & & & & $\begin{array}{c}0.00915 * * * \\
(0.000985)\end{array}$ & $\begin{array}{c}0.00898 * * * \\
(0.000986)\end{array}$ & $\begin{array}{c}0.00894 * * * \\
(0.000989)\end{array}$ & $\begin{array}{c}0.0233^{* * *} \\
(0.00213)\end{array}$ \\
\hline CA*Post & $\begin{array}{c}0.00880 * * * \\
(0.00177)\end{array}$ & & & & & & \\
\hline Post*Under1 & & $\begin{array}{c}0.0102 * * * \\
(0.00324)\end{array}$ & $\begin{array}{c}0.0125 * * * \\
(0.00338)\end{array}$ & & & & \\
\hline Observations & 251,685 & 109,064 & 99,688 & 879,873 & 878,377 & 878,377 & 682,872 \\
\hline R-squared & 0.013 & 0.014 & 0.013 & 0.013 & 0.012 & 0.011 & 0.057 \\
\hline Individual Controls & YES & YES & YES & YES & YES & YES & YES \\
\hline State-Year Controls & YES & NO & $\mathrm{NO}$ & NO & YES & YES & NO \\
\hline Time FE & YES & YES & YES & YES & YES & YES & YES \\
\hline State FE & YES & NO & NO & YES & YES & YES & YES \\
\hline State-Year FE & NO & $\mathrm{NO}$ & NO & YES & $\mathrm{NO}$ & $\mathrm{NO}$ & YES \\
\hline State Linear Trend & $\mathrm{NO}$ & NO & $\mathrm{NO}$ & NO & YES & NO & $\mathrm{NO}$ \\
\hline Pre-Treatment Mean for CA Parents of Infants & 0.0199 & 0.0199 & 0.0199 & 0.0199 & 0.0199 & 0.0199 & 0.177 \\
\hline
\end{tabular}

Notes: Robust standard errors in parentheses. In all tables, specifications that compare across states have cluster-robust standard errors, clustered at the state level. Coefficient of interest (DD or DDD) is shown. Individual controls include dummies for age of youngest child, number of children, citizenship status, marital status, 5-year age bins, race (White, Black, Hispanic, Asian, Other), education level (less than high school, high school, some college, 4-year degree or higher), and indicators for employed and in the labor force. State-Year controls include unemployment rate, average welfare benefit for a 4 person family, poverty rate, an indicator for whether the governor is democratic, state minimum wage, log of population, and per capita income. DD state indicates a DD model comparing fathers of a youngest child under 1 year in California to fathers with a child under 1 in other states; DD 1-3 and DD 2-4 compare fathers with a child under 1 year in California to fathers in California with a youngest child aged 1-3 or 2-4, respectively; and DDD 1-3 compares fathers of infants to fathers with a youngest child aged 1-3, in California versus other states, before and after the policy. The "All Parents" sample includes all employed fathers or mothers.

*** $\mathrm{p}<0.01, * * \mathrm{p}<0.05,{ }^{*} \mathrm{p}<0.1$ 
Table 3: Effects of CA-PFL on Household Leave-Taking Behavior

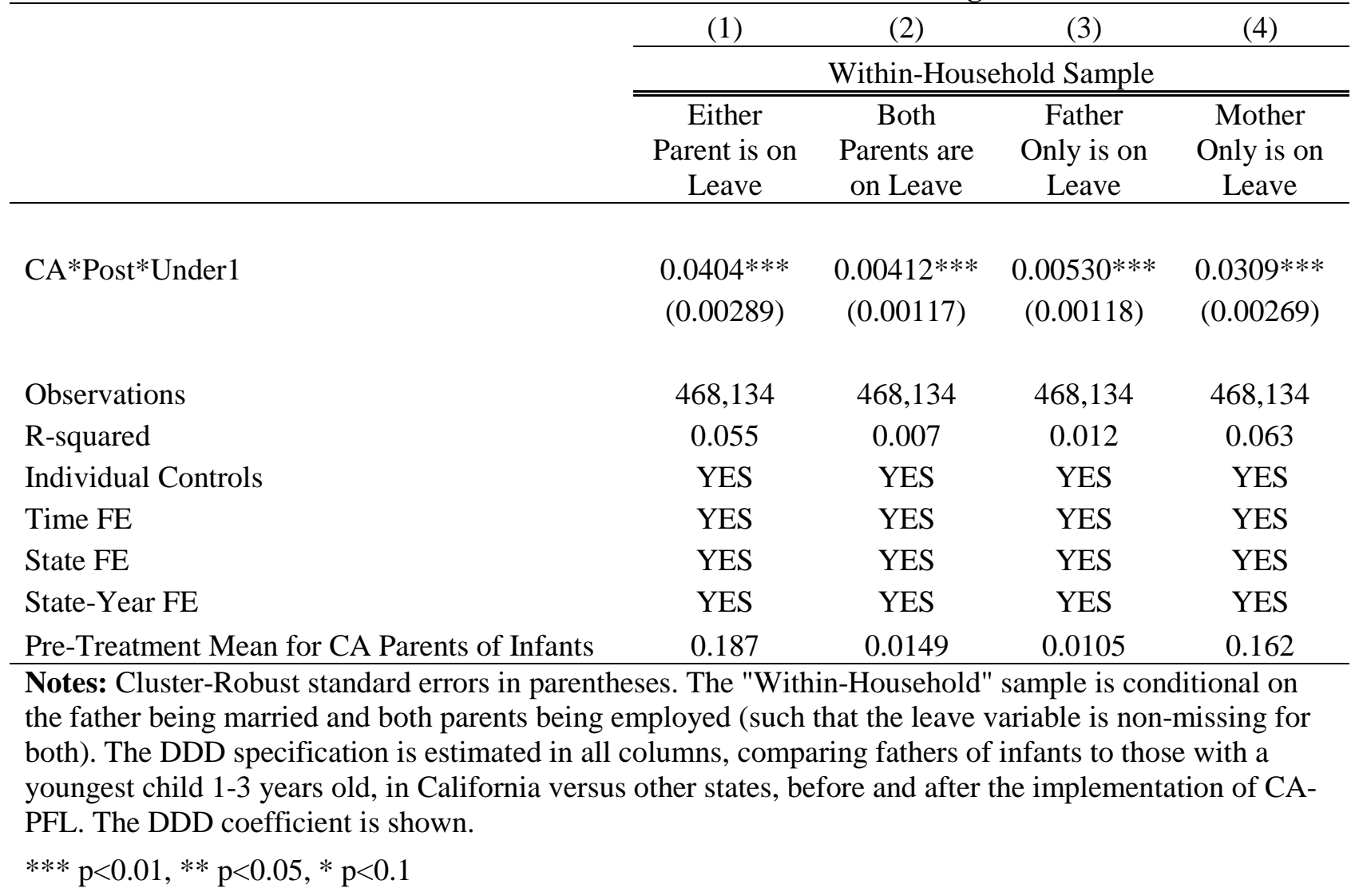


Table 4: Heterogeneous Effects by Gender of Youngest Child

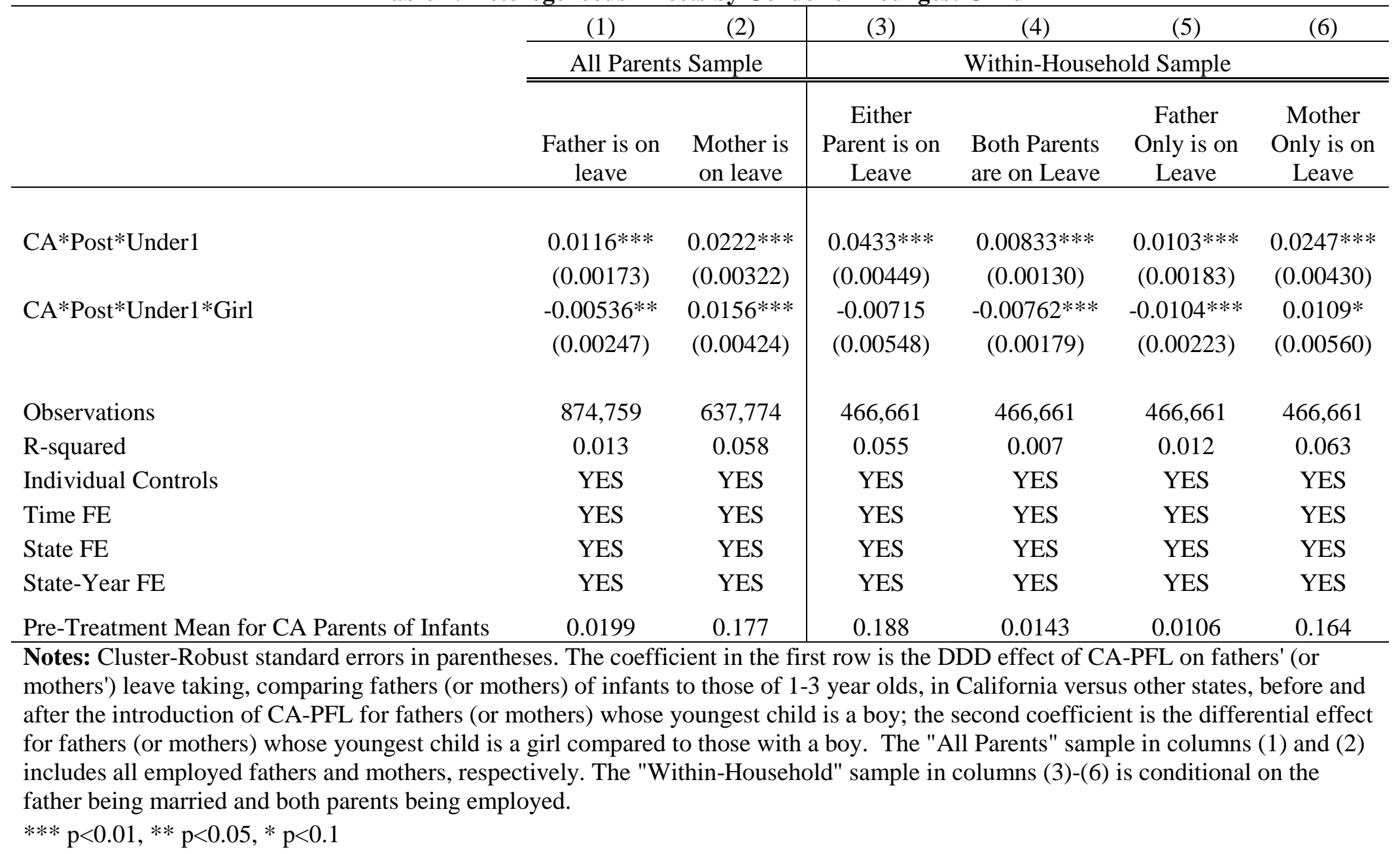


Table 5: Heterogeneous Effects by Child Parity

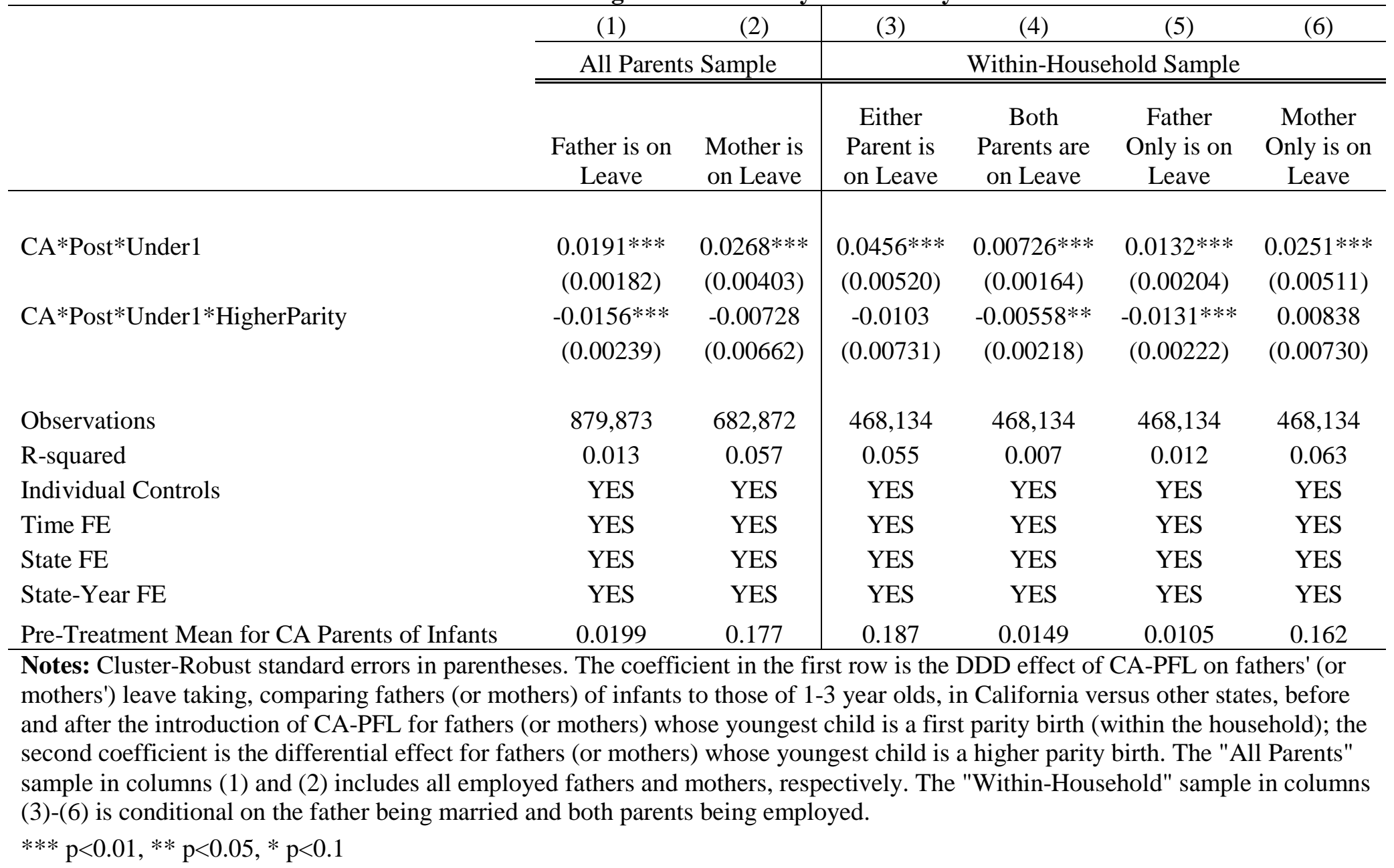


Table 6: Heterogeneous Effects by High/Low Female Share in Occupation

\begin{tabular}{|c|c|c|}
\hline & $(1)$ & $(2)$ \\
\hline & All Pare & Sample \\
\hline & $\begin{array}{c}\text { Father is on } \\
\text { Leave }\end{array}$ & $\begin{array}{c}\text { Mother is on } \\
\text { Leave }\end{array}$ \\
\hline CA*Post*Under1 & $0.00785^{* * *}$ & -0.0129 \\
\hline & $(0.00118)$ & $(0.00989)$ \\
\hline CA*Post*Under1*HighFemaleShare & $0.00324 *$ & $0.0421 * * *$ \\
\hline & $(0.00190)$ & $(0.0104)$ \\
\hline Observations & 879,290 & 682,522 \\
\hline R-squared & 0.013 & 0.057 \\
\hline Individual Controls & YES & YES \\
\hline Time FE & YES & YES \\
\hline State FE & YES & YES \\
\hline State-Year FE & YES & YES \\
\hline Pre-Treatment Mean for CA Parents of Infants & 0.0200 & 0.176 \\
\hline $\begin{array}{l}\text { Notes: The share of female workers in each occ } \\
2000 \text { Census. High female share occupations ar } \\
\text { robust standard errors in parentheses. }\end{array}$ & $\begin{array}{l}\text { on is calculat } \\
\text { e above the } ~\end{array}$ & $\begin{array}{l}\text { using the } \\
\text { lian. Cluster- }\end{array}$ \\
\hline$* * * \mathrm{p}<0.01, * * \mathrm{p}<0.05, * \mathrm{p}<0.1$ & & \\
\hline
\end{tabular}


Table 7: Estimates Based on Collapsed Data

\begin{tabular}{|c|c|c|c|c|c|c|c|c|c|c|c|}
\hline & $(1)$ & $(2)$ & $(3)$ & (4) & (5) & (6) & $(7)$ & $(8)$ & $(9)$ & $(10)$ & $(11)$ \\
\hline & \multicolumn{11}{|c|}{ Outcome: Father is on Leave } \\
\hline & $\begin{array}{c}\text { Not } \\
\text { Matched }\end{array}$ & $\begin{array}{c}\text { Synthetic } \\
1 \\
\end{array}$ & $\begin{array}{c}\text { Synthetic } \\
2 \\
\end{array}$ & $\begin{array}{c}\text { Synthetic } \\
3 \\
\end{array}$ & $\begin{array}{c}\text { Synthetic } \\
4 \\
\end{array}$ & $\begin{array}{c}\text { Synthetic } \\
5 \\
\end{array}$ & $\begin{array}{c}\text { Synthetic } \\
6 \\
\end{array}$ & $\begin{array}{c}\text { Synthetic } \\
7 \\
\end{array}$ & $\begin{array}{c}\text { Synthetic } \\
8 \\
\end{array}$ & $\begin{array}{c}\text { Synthetic } \\
9 \\
\end{array}$ & $\begin{array}{c}\text { Synthetic } \\
10 \\
\end{array}$ \\
\hline CA*Post & $\begin{array}{l}0.00809 * \\
(0.00391)\end{array}$ & $\begin{array}{c}0.00968 * * \\
(0.00398)\end{array}$ & $\begin{array}{l}0.0107^{* *} \\
(0.00459)\end{array}$ & $\begin{array}{c}0.0107 \\
(0.00628)\end{array}$ & $\begin{array}{l}0.0137 * * \\
(0.00496)\end{array}$ & $\begin{array}{l}0.0139 * * \\
(0.00486)\end{array}$ & $\begin{array}{l}0.0144 * * \\
(0.00475)\end{array}$ & $\begin{array}{l}0.0133 * * \\
(0.00472)\end{array}$ & $\begin{array}{l}0.0107^{* *} \\
(0.00459)\end{array}$ & $\begin{array}{l}0.0134 * * \\
(0.00445)\end{array}$ & $\begin{array}{l}0.0132 * * \\
(0.00515)\end{array}$ \\
\hline Observations & 14 & 14 & 14 & 14 & 14 & 14 & 14 & 14 & 14 & 14 & 14 \\
\hline R-squared & 0.324 & 0.330 & 0.310 & 0.195 & 0.388 & 0.405 & 0.433 & 0.399 & 0.310 & 0.430 & 0.353 \\
\hline Individual Controls & YES & NO & NO & NO & NO & NO & NO & NO & NO & NO & NO \\
\hline State-Year Controls & NO & NO & NO & NO & NO & NO & NO & NO & NO & NO & NO \\
\hline Time FE & YES & NO & NO & NO & NO & NO & NO & NO & NO & NO & NO \\
\hline State FE & YES & NO & NO & NO & NO & NO & NO & NO & NO & NO & NO \\
\hline State-Year FE & NO & NO & NO & NO & NO & NO & NO & NO & NO & NO & NO \\
\hline Pre-Treatment Mean in CA & 0.0203 & 0.0211 & 0.0211 & 0.0211 & 0.0211 & 0.0211 & 0.0211 & 0.0211 & 0.0211 & 0.0211 & 0.0211 \\
\hline
\end{tabular}

Notes: Donald-Lang standard errors in parentheses. The samples compare fathers of infants in California to fathers of infants in other states. The first column shows the specification from Column 1, Table 3 using the Donald-Lang method to adjust the standard errors. Columns 2-11 show the raw DD effect of fathers of infants in California compared to fathers of infants in the synthetic control state, matched on different sets of variables. Synthetic 1 matches on the share of fathers on leave averaged over the pre-treatment period; Synthetic 2 matches on share on leave in each year of the pre-treatment period; Synthetic 3 matches on leave, share employed, and share in the labor force averaged over the pre-treatment period; Synthetic 4 matches on share on leave, employed, labor force, and race in the pre-treatment period; Synthetic 5 matches on share on leave in the pre-treatment period and share employed, in the labor force, and race averaged over the whole period; Synthetic 6 matches on the share on leave, employed, in labor force, race, and education averaged over the pre-treatment period; Synthetic 7 matches on share on leave in the pre-treatment period and share employed, in the labor force, race, and education averaged over the whole period; Synthetic 8 matches on share on leave in each year of the pre-treatment period and race and education averaged over the whole period; Synthetic 9 matches on 2 year averages of the share on leave in the pre-treatment period and race and education averaged over the whole period; and Synthetic 10 matches on share on leave averaged over the pretreatment period and race and education averaged over the whole period.

${ }^{* * *} \mathrm{p}<0.01,{ }^{* *} \mathrm{p}<0.05,{ }^{*} \mathrm{p}<0.1$ 
Appendix Table A1: Summary Statistics

\begin{tabular}{|c|c|c|c|c|c|c|c|c|c|c|}
\hline & \multicolumn{5}{|c|}{ Employed Fathers } & \multicolumn{5}{|c|}{ Employed Mothers } \\
\hline & $\begin{array}{c}\text { Youngest } \\
\text { Child 0- } \\
\text { 3, All } \\
\text { States }\end{array}$ & $\begin{array}{c}\text { Youngest } \\
\text { Child }<1 \text {, } \\
\text { CA }\end{array}$ & $\begin{array}{c}\text { Youngest } \\
\text { Child }<1 \text {, } \\
\text { Other } \\
\text { States }\end{array}$ & $\begin{array}{c}\text { Youngest } \\
\text { Child 1- } \\
\text { 3, CA }\end{array}$ & $\begin{array}{c}\text { Youngest } \\
\text { Child 1-3, } \\
\text { Other } \\
\text { States }\end{array}$ & $\begin{array}{c}\text { Youngest } \\
\text { Child 0- } \\
\text { 3, All } \\
\text { States }\end{array}$ & $\begin{array}{c}\text { Youngest } \\
\text { Child }<1 \text {, } \\
\text { CA }\end{array}$ & $\begin{array}{c}\text { Youngest } \\
\text { Child <1, } \\
\text { Other } \\
\text { States }\end{array}$ & $\begin{array}{c}\text { Youngest } \\
\text { Child 1- } \\
\text { 3, CA }\end{array}$ & $\begin{array}{c}\text { Youngest } \\
\text { Child 1-3, } \\
\text { Other } \\
\text { States }\end{array}$ \\
\hline Age & $\begin{array}{l}33.554 \\
(0.007)\end{array}$ & $\begin{array}{l}33.061 \\
(0.037)\end{array}$ & $\begin{array}{l}32.002 \\
(0.013)\end{array}$ & $\begin{array}{l}34.762 \\
(0.024)\end{array}$ & $\begin{array}{l}34.019 \\
(0.009)\end{array}$ & $\begin{array}{l}30.848 \\
(0.007)\end{array}$ & $\begin{array}{l}30.836 \\
(0.042)\end{array}$ & $\begin{array}{l}29.612 \\
(0.015)\end{array}$ & $\begin{array}{l}32.107 \\
(0.027)\end{array}$ & $\begin{array}{l}31.114 \\
(0.009)\end{array}$ \\
\hline Married & $\begin{array}{c}0.909 \\
(0.000)\end{array}$ & $\begin{array}{c}0.895 \\
(0.002)\end{array}$ & $\begin{array}{c}0.905 \\
(0.001)\end{array}$ & $\begin{array}{c}0.902 \\
(0.001)\end{array}$ & $\begin{array}{c}0.914 \\
(0.000)\end{array}$ & $\begin{array}{c}0.706 \\
(0.001)\end{array}$ & $\begin{array}{c}0.760 \\
(0.003)\end{array}$ & $\begin{array}{c}0.735 \\
(0.001)\end{array}$ & $\begin{array}{c}0.724 \\
(0.002)\end{array}$ & $\begin{array}{c}0.692 \\
(0.001)\end{array}$ \\
\hline Citizen & $\begin{array}{c}0.850 \\
(0.000)\end{array}$ & $\begin{array}{c}0.695 \\
(0.003)\end{array}$ & $\begin{array}{c}0.874 \\
(0.001)\end{array}$ & $\begin{array}{c}0.685 \\
(0.002)\end{array}$ & $\begin{array}{c}0.875 \\
(0.000)\end{array}$ & $\begin{array}{c}0.909 \\
(0.000)\end{array}$ & $\begin{array}{c}0.799 \\
(0.003)\end{array}$ & $\begin{array}{c}0.927 \\
(0.001)\end{array}$ & $\begin{array}{c}0.790 \\
(0.002)\end{array}$ & $\begin{array}{c}0.922 \\
(0.000)\end{array}$ \\
\hline White & $\begin{array}{c}0.653 \\
(0.001)\end{array}$ & $\begin{array}{c}0.378 \\
(0.003)\end{array}$ & $\begin{array}{c}0.700 \\
(0.001)\end{array}$ & $\begin{array}{c}0.360 \\
(0.002)\end{array}$ & $\begin{array}{c}0.697 \\
(0.001)\end{array}$ & $\begin{array}{c}0.633 \\
(0.001)\end{array}$ & $\begin{array}{c}0.388 \\
(0.003)\end{array}$ & $\begin{array}{c}0.685 \\
(0.001)\end{array}$ & $\begin{array}{c}0.360 \\
(0.002)\end{array}$ & $\begin{array}{c}0.660 \\
(0.001)\end{array}$ \\
\hline Black & $\begin{array}{c}0.077 \\
(0.000)\end{array}$ & $\begin{array}{c}0.037 \\
(0.001)\end{array}$ & $\begin{array}{c}0.081 \\
(0.001)\end{array}$ & $\begin{array}{c}0.041 \\
(0.001)\end{array}$ & $\begin{array}{c}0.083 \\
(0.000)\end{array}$ & $\begin{array}{c}0.141 \\
(0.000)\end{array}$ & $\begin{array}{c}0.060 \\
(0.002)\end{array}$ & $\begin{array}{c}0.139 \\
(0.001)\end{array}$ & $\begin{array}{c}0.071 \\
(0.001)\end{array}$ & $\begin{array}{c}0.154 \\
(0.001)\end{array}$ \\
\hline Hispanic & $\begin{array}{c}0.199 \\
(0.000)\end{array}$ & $\begin{array}{c}0.437 \\
(0.003)\end{array}$ & $\begin{array}{c}0.160 \\
(0.001)\end{array}$ & $\begin{array}{c}0.452 \\
(0.002)\end{array}$ & $\begin{array}{c}0.161 \\
(0.000)\end{array}$ & $\begin{array}{c}0.160 \\
(0.000)\end{array}$ & $\begin{array}{c}0.382 \\
(0.003)\end{array}$ & $\begin{array}{c}0.121 \\
(0.001)\end{array}$ & $\begin{array}{c}0.404 \\
(0.002)\end{array}$ & $\begin{array}{c}0.132 \\
(0.001)\end{array}$ \\
\hline Asian & $\begin{array}{c}0.060 \\
(0.000)\end{array}$ & $\begin{array}{c}0.136 \\
(0.002)\end{array}$ & $\begin{array}{c}0.047 \\
(0.000)\end{array}$ & $\begin{array}{c}0.138 \\
(0.001)\end{array}$ & $\begin{array}{c}0.048 \\
(0.000)\end{array}$ & $\begin{array}{c}0.054 \\
(0.000)\end{array}$ & $\begin{array}{c}0.155 \\
(0.003)\end{array}$ & $\begin{array}{c}0.042 \\
(0.001)\end{array}$ & $\begin{array}{c}0.153 \\
(0.002)\end{array}$ & $\begin{array}{c}0.040 \\
(0.000)\end{array}$ \\
\hline Less than high school & $\begin{array}{c}0.133 \\
(0.000)\end{array}$ & $\begin{array}{c}0.213 \\
(0.002)\end{array}$ & $\begin{array}{c}0.121 \\
(0.001)\end{array}$ & $\begin{array}{c}0.228 \\
(0.001)\end{array}$ & $\begin{array}{c}0.119 \\
(0.000)\end{array}$ & $\begin{array}{c}0.090 \\
(0.000)\end{array}$ & $\begin{array}{c}0.122 \\
(0.002)\end{array}$ & $\begin{array}{c}0.079 \\
(0.001)\end{array}$ & $\begin{array}{c}0.145 \\
(0.001)\end{array}$ & $\begin{array}{c}0.086 \\
(0.000)\end{array}$ \\
\hline High School Diploma & $\begin{array}{c}0.245 \\
(0.000)\end{array}$ & $\begin{array}{c}0.203 \\
(0.002)\end{array}$ & $\begin{array}{c}0.246 \\
(0.001)\end{array}$ & $\begin{array}{c}0.206 \\
(0.001)\end{array}$ & $\begin{array}{c}0.253 \\
(0.001)\end{array}$ & $\begin{array}{c}0.223 \\
(0.001)\end{array}$ & $\begin{array}{c}0.185 \\
(0.003)\end{array}$ & $\begin{array}{c}0.212 \\
(0.001)\end{array}$ & $\begin{array}{c}0.204 \\
(0.002)\end{array}$ & $\begin{array}{c}0.231 \\
(0.001)\end{array}$ \\
\hline Some College & $\begin{array}{c}0.283 \\
(0.000)\end{array}$ & $\begin{array}{c}0.259 \\
(0.003)\end{array}$ & $\begin{array}{c}0.285 \\
(0.001)\end{array}$ & $\begin{array}{c}0.258 \\
(0.002)\end{array}$ & $\begin{array}{c}0.287 \\
(0.001)\end{array}$ & $\begin{array}{c}0.338 \\
(0.001)\end{array}$ & $\begin{array}{c}0.321 \\
(0.003)\end{array}$ & $\begin{array}{c}0.324 \\
(0.001)\end{array}$ & $\begin{array}{c}0.329 \\
(0.002)\end{array}$ & $\begin{array}{c}0.345 \\
(0.001)\end{array}$ \\
\hline BA or higher & $\begin{array}{c}0.339 \\
(0.001)\end{array}$ & $\begin{array}{c}0.325 \\
(0.003)\end{array}$ & $\begin{array}{c}0.348 \\
(0.001)\end{array}$ & $\begin{array}{c}0.308 \\
(0.002)\end{array}$ & $\begin{array}{c}0.341 \\
(0.001)\end{array}$ & $\begin{array}{c}0.349 \\
(0.001)\end{array}$ & $\begin{array}{c}0.372 \\
(0.003)\end{array}$ & $\begin{array}{c}0.385 \\
(0.001)\end{array}$ & $\begin{array}{c}0.323 \\
(0.002)\end{array}$ & $\begin{array}{c}0.338 \\
(0.001)\end{array}$ \\
\hline Usual Hours Worked & $\begin{array}{l}44.852 \\
(0.011)\end{array}$ & $\begin{array}{l}43.670 \\
(0.059)\end{array}$ & $\begin{array}{l}44.837 \\
(0.023)\end{array}$ & $\begin{array}{l}43.739 \\
(0.037)\end{array}$ & $\begin{array}{l}45.101 \\
(0.014)\end{array}$ & $\begin{array}{l}35.759 \\
(0.014)\end{array}$ & $\begin{array}{l}36.144 \\
(0.078)\end{array}$ & $\begin{array}{l}35.998 \\
(0.028)\end{array}$ & $\begin{array}{l}35.838 \\
(0.048)\end{array}$ & $\begin{array}{l}35.649 \\
(0.017)\end{array}$ \\
\hline On Leave & 0.021 & 0.028 & 0.022 & 0.024 & 0.019 & 0.064 & 0.199 & 0.148 & 0.040 & 0.032 \\
\hline
\end{tabular}




\begin{tabular}{|c|c|c|c|c|c|c|c|c|c|c|}
\hline & $(0.000)$ & $(0.001)$ & $(0.000)$ & $(0.001)$ & $(0.000)$ & $(0.000)$ & $(0.003)$ & $(0.001)$ & $(0.001)$ & $(0.000)$ \\
\hline Total Household Income & $\begin{array}{c}86,122.59 \\
(82.515)\end{array}$ & $\begin{array}{l}93,164.62 \\
(494.842)\end{array}$ & $\begin{array}{l}82,412.74 \\
(157.089)\end{array}$ & $\begin{array}{l}94,140.33 \\
(310.324)\end{array}$ & $\begin{array}{l}85,947.91 \\
(103.203)\end{array}$ & $\begin{array}{c}81,607.77 \\
(89.094)\end{array}$ & $\begin{array}{c}100,429.75 \\
(646.093)\end{array}$ & $\begin{array}{l}81,544.49 \\
(181.592)\end{array}$ & $\begin{array}{l}95,840.09 \\
(364.376)\end{array}$ & $\begin{array}{l}78,968.89 \\
(106.213)\end{array}$ \\
\hline Total Personal Income & $\begin{array}{c}59,926.93 \\
(67.567)\end{array}$ & $\begin{array}{l}61,722.46 \\
(384.039)\end{array}$ & $\begin{array}{l}56,407.75 \\
(125.602)\end{array}$ & $\begin{array}{l}64,420.77 \\
(252.047)\end{array}$ & $\begin{array}{c}60,536.90 \\
(85.744)\end{array}$ & $\begin{array}{c}33,305.20 \\
(44.094)\end{array}$ & $\begin{array}{l}39,925.57 \\
(325.882)\end{array}$ & $\begin{array}{c}33,056.39 \\
(89.542)\end{array}$ & $\begin{array}{l}38,288.22 \\
(179.229)\end{array}$ & $\begin{array}{c}32,458.47 \\
(52.753)\end{array}$ \\
\hline $\mathrm{N}$ & 879,873 & 30,534 & 221,664 & 78,530 & 549,145 & 682,872 & 19,428 & 159,961 & 55,390 & 448,093 \\
\hline
\end{tabular}

Notes: Standard errors in parentheses. In the first 5 columns, the sample is limited to employed fathers 16-54 years old. In the subsequent 5 columns, the sample is limited to employed mothers 16-54 years old. Statistics are weighted by the ACS person weights. 


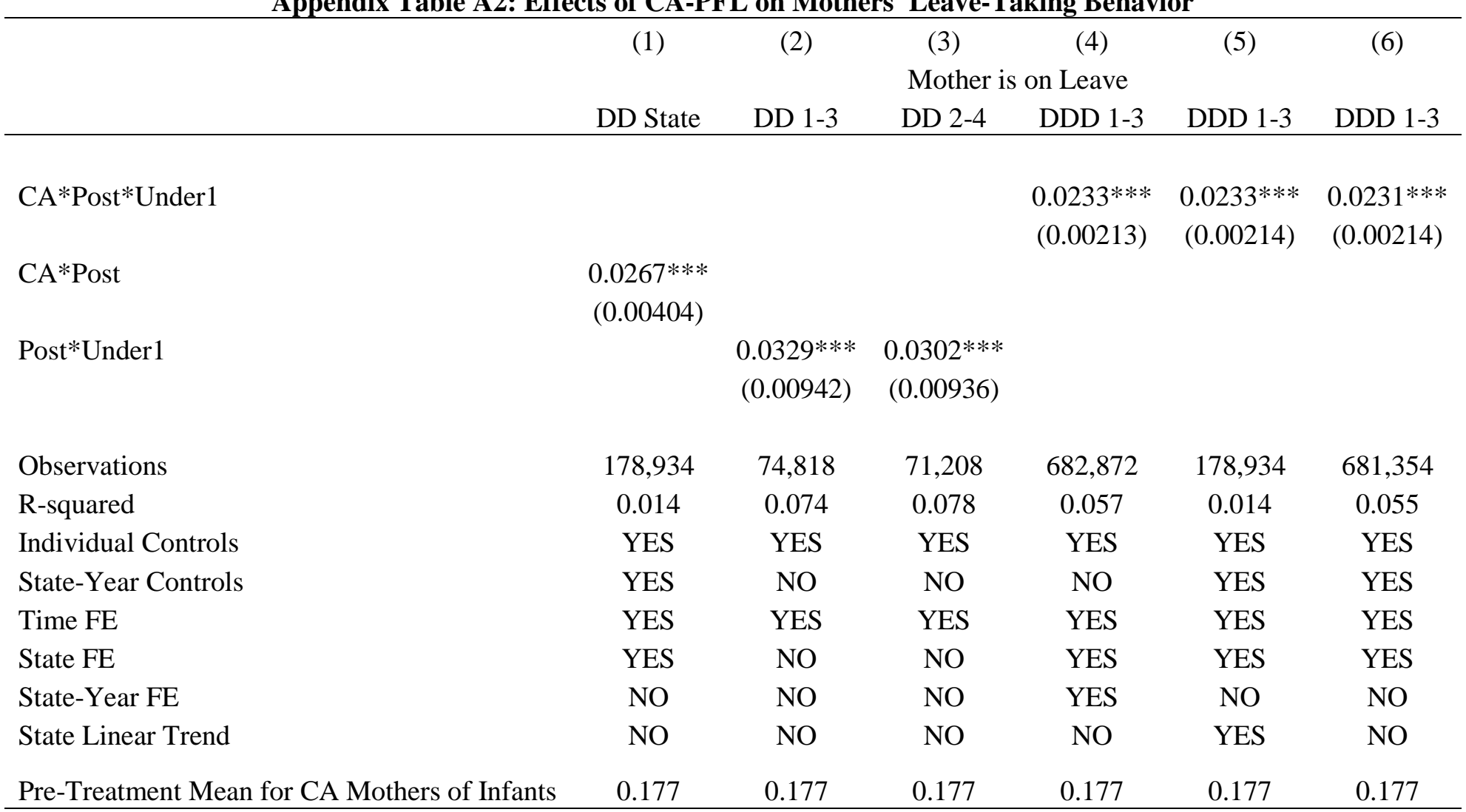

Notes: Robust standard errors in parentheses. Specifications that compare across states have cluster-robust standard errors, clustered at the state level. This table replicates Table 2, looking at the effect of CA-PFL on mothers instead of fathers. The sample includes all employed mothers.

$* * * \mathrm{p}<0.01, * * \mathrm{p}<0.05, * \mathrm{p}<0.1$ 
Appendix Table A3: Results Excluding Controls and Excluding Year 2000

\begin{tabular}{|c|c|c|c|c|c|c|c|c|}
\hline & $(1)$ & $(2)$ & (3) & (4) & (9) & $(10)$ & $(11)$ & $(12)$ \\
\hline & \multicolumn{8}{|c|}{ Outcome: Father is on Leave, All Parents Sample } \\
\hline & \multicolumn{4}{|c|}{ Excluding Controls } & \multicolumn{4}{|c|}{ Excluding Year 2000} \\
\hline & DD State & DD 1-3 & DD 2-4 & DDD 1-3 & DD State & DD 1-3 & DD 2-4 & DDD 1-3 \\
\hline CA*Post*Under1 & & & & $\begin{array}{c}0.00882^{* * *} \\
(0.00104)\end{array}$ & & & & $\begin{array}{c}0.00731^{* * * *} \\
(0.00116)\end{array}$ \\
\hline CA*Post & $\begin{array}{l}0.0117 * * * \\
(0.000853)\end{array}$ & & & & $\begin{array}{c}0.00945^{* * *} \\
(0.00191)\end{array}$ & & & \\
\hline Post*Under1 & & $\begin{array}{c}0.0100 * * * \\
(0.00328)\end{array}$ & $\begin{array}{c}0.0122 * * * \\
(0.00342)\end{array}$ & & & $\begin{array}{c}0.00830 * * \\
(0.00358)\end{array}$ & $\begin{array}{c}0.00997^{* * *} \\
(0.00367)\end{array}$ & \\
\hline Observations & 252,198 & 109,064 & 99,688 & 879,873 & 224,937 & 97,683 & 89,427 & 789,026 \\
\hline R-squared & 0.002 & 0.001 & 0.001 & 0.002 & 0.010 & 0.009 & 0.008 & 0.009 \\
\hline Individual Controls & NO & NO & NO & NO & YES & YES & YES & YES \\
\hline State-Year Controls & NO & NO & NO & NO & YES & NO & NO & NO \\
\hline Time FE & YES & YES & YES & YES & YES & YES & YES & YES \\
\hline State FE & YES & NO & NO & YES & YES & NO & NO & YES \\
\hline State-Year FE & NO & NO & NO & YES & NO & NO & NO & YES \\
\hline $\begin{array}{l}\text { Pre-Treatment Mean for } \\
\text { CA Fathers of Infants }\end{array}$ & 0.0199 & 0.0199 & 0.0199 & 0.0199 & 0.0226 & 0.0226 & 0.0226 & 0.0226 \\
\hline
\end{tabular}

Notes: Robust standard errors in parentheses. Specifications that compare across states have cluster-robust standard errors, clustered at the state level. This table replicates the first four columns of Table 2, but Columns (1)-(4) omit individual and state-year controls, columns (5)-(8) do not use the ACS sampling weights, and columns (9)-(12) exclude observations from 2000 because the Census might be different from the ACS. The sample includes all employed fathers.

$* * * \mathrm{p}<0.01, * * \mathrm{p}<0.05, * \mathrm{p}<0.1$ 
Appendix Table A4: Estimates Based on Alternative Samples of Fathers

\begin{tabular}{|c|c|c|c|c|c|c|c|c|}
\hline & $(1)$ & $(2)$ & (3) & $(4)$ & $(5)$ & $(6)$ & (7) & (8) \\
\hline & \multicolumn{8}{|c|}{ Outcome: Father is on Leave } \\
\hline & \multicolumn{4}{|c|}{ Father worked at least one week last year } & \multicolumn{4}{|c|}{ All fathers } \\
\hline & DD State & DD 1-3 & DD 2-4 & DDD 1-3 & DD State & DD 1-3 & DD 2-4 & DDD 1-3 \\
\hline CA*Post*Under1 & & & & $\begin{array}{c}0.00804 * * * \\
(0.000959)\end{array}$ & & & & $\begin{array}{c}0.00755^{* * *} \\
(0.000923)\end{array}$ \\
\hline CA*Post & $\begin{array}{l}0.0107 * * * \\
(0.000793)\end{array}$ & & & & $\begin{array}{c}0.00735^{* * *} \\
(0.00158)\end{array}$ & & & \\
\hline Post*Under1 & & $\begin{array}{c}0.00907^{* * *} \\
(0.00298)\end{array}$ & $\begin{array}{c}0.0112 * * * \\
(0.00311)\end{array}$ & & & $\begin{array}{c}0.00857^{* * *} \\
(0.00287)\end{array}$ & $\begin{array}{c}0.0108 * * * \\
(0.00300)\end{array}$ & \\
\hline Observations & 269,551 & 117,707 & 107,542 & 937,452 & 279,603 & 123,769 & 113,194 & 976,475 \\
\hline $\begin{array}{l}\text { R-squared } \\
\text { Individual }\end{array}$ & 0.003 & 0.004 & 0.004 & 0.004 & 0.004 & 0.004 & 0.004 & 0.004 \\
\hline $\begin{array}{l}\text { Controls } \\
\text { State-Year }\end{array}$ & YES & YES & YES & YES & YES & YES & YES & YES \\
\hline Controls & YES & NO & NO & NO & YES & NO & NO & NO \\
\hline Time FE & YES & YES & YES & YES & YES & YES & YES & YES \\
\hline State FE & YES & NO & NO & YES & YES & NO & NO & YES \\
\hline State-Year FE & NO & NO & NO & YES & NO & NO & NO & YES \\
\hline Mean & 0.0181 & 0.0181 & 0.0181 & 0.0181 & 0.0176 & 0.0176 & 0.0176 & 0.0176 \\
\hline
\end{tabular}

Notes: Robust standard errors in parentheses. Specifications that compare across states have cluster-robust standard errors, clustered at the state level. This table replicates the first four columns of Table 2, but includes all fathers who worked at least one week in the previous year in columns (1)-(4), instead of conditioning on employed fathers. Columns (5)-(8) include all fathers, regardless of employment status.

$* * * \mathrm{p}<0.01, * * \mathrm{p}<0.05, * \mathrm{p}<0.1$ 